Article

\title{
Novel 6a,12b-Dihydro-6H,7H-chromeno[3,4-c] chromen-6-ones: Synthesis, Structure and Antifungal Activity
}

\author{
Jin-ping Bao ${ }^{1} \mathbb{C}$, Cui-lian Xu ${ }^{2, *}$, Guo-yu Yang ${ }^{2, *}$, Cai-xia Wang ${ }^{2}$, Xin Zheng ${ }^{2}$ and Xin-xin Yuan ${ }^{1}$ \\ 1 College of Resource and Environment; Henan Agricultural University, Zhengzhou 450002, China; \\ baojinping666@126.com (J.-p.B.); 18339992125@163.com (X.-x.Y.) \\ 2 School of Science, Henan Agricultural University, Zhengzhou 450002, China; wcx670815@163.com (C.-x.W.); \\ zhengxin@henau.edu.cn (X.Z.) \\ * Correspondence: xucuilian666@henau.edu.cn (C.-1.X.); yangguoyulxy@henau.edu.cn (G.-y.Y.); \\ Tel.: +86-371-6355-8661 (C.-1.X.); Fax: +86-371-6355-8881 (C.-1.X.)
}

Academic Editor: Gianfranco Favi

Received: 19 March 2019; Accepted: 3 May 2019; Published: 5 May 2019

\begin{abstract}
A new series of coumarin derivatives, 7-hydroxy-7-(trifluoromethyl)-6a,12b-dihydro- $6 \mathrm{H}, 7 \mathrm{H}$ chromeno[3,4-c]chromen-6-ones 3a-p, were synthesized via Michael addition, transesterification and nucleophilic addition from the reaction of 3-trifluoroacetyl coumarins and phenols in the presence of an organic base. The products were characterized by infrared spectroscopy (IR), hydrogen nuclear magnetic resonance spectroscopy $\left({ }^{1} \mathrm{H}-\mathrm{NMR}\right)$, carbon nuclear magnetic resonance spectroscopy $\left({ }^{13} \mathrm{C}-\mathrm{NMR}\right)$ and high-resolution mass spectrometer (HRMS). Single crystal X-ray analysis of compounds $\mathbf{3 a}$ and $\mathbf{3 n}$ clearly confirmed their assigned chemical structures and their twisted conformations. Compound 3a crystallized in the orthorhombic system, Pbca, in which a $=8.6244(2) \AA$, $\mathrm{b}=17.4245(4) \AA, \mathrm{c}=22.5188(6) \AA, \alpha=90^{\circ}, \beta=90^{\circ}, \gamma=90^{\circ}, \mathrm{v}=3384.02(14) \AA^{3}$, and $\mathrm{z}=8$. In addition, the mycelial growth rate method was used to examine the in vitro antifungal activities of the title compounds 3a-p against Fusarium graminearum and Fusarium monitiforme at $500 \mu \mathrm{g} / \mathrm{mL}$. The results showed that compound 31 exhibited significant anti-Fusarium monitiforme activity with inhibitory index of $84.6 \%$.
\end{abstract}

Keywords: dihydrocoumarins; synthesis; 3-trifluoroacetyl coumarins; phenols; antifungal activities

\section{Introduction}

Many natural compounds, such as coumarins, have commonly been used as meaningful lead compounds in the founding of some newer pharmaceuticals [1,2]. Coumarins belong to a class of notable heterocycle compounds containing oxygen, which exhibit various biological activities, including antioxidant [3], antitubercular [4], antitumor [5], antifungal [6], antibacterial [7], antiviral [8], antileishmanial [9], and anticancer [10] activities.

4-Arylcoumarins (neoflavones), present in many natural compounds, are considered important privileged structures due to their diverse biological activities, such as anticancer [11], antioxidant [12], antimicrobial [13], antiprotozoal [14] and antifungal activities [15]. Many studies have focused on the synthetic methods and structure-activity relationship research of 4-arylcoumarins, expecting to discover novel lead compounds [16].

Recently, heterocyclic fused coumarin derivatives from natural or non-natural products have attracted great interest from chemists and pharmaceutical scientists. For instance, pyrano-fused coumarin derivatives have shown much higher antifungal activities [17], and compounds containing thieno[3,2-c]coumarin and pyrazolo[4,3-c]coumarin frameworks demonstrated considerable antifungal and antibacterial activities in the in vitro test systems [18]. 
The attachment of a fluorine atom or fluorine-containing functional groups to heterocycle molecules often results in an increase in their lipophilicity, metabolic stability and bioactivity [19]. Trifluoromethyl ketones can be used as a typical structural framework to incorporate $\mathrm{CF}_{3}$ in the target compounds [20-23]. Keeping these aspects in mind, we adopted 3-trifluoroacetyl coumarins as a building block to synthesize novel coumarins containing fluorine [24].

Here, we report the unexpected synthesis of a series of novel dihydrocoumarins or benzopyran fused dihydrocoumarins, chromeno [3,4-c]chromen-6-ones and the preliminary evaluation of their antifungal activities.

\section{Results and Discussion}

\subsection{Chemistry}

Fan et al. reported a tandem reaction of $\alpha, \beta$-unsaturated trifluoromethyl ketones with 2-naphthol to obtain the corresponding benzo[f]chromene derivatives in the presence of catalysts with a one-pot reaction (Scheme 1) [25]. According to the literature, an 1,4-addition reaction should take place between $\alpha, \beta$-unsaturated trifluoromethyl ketones and 2-naphthols under the catalysis of a weak base.<smiles></smiles><smiles>[R]C1C=C(C(F)(F)F)Oc2ccc3ccccc3c21</smiles>

Scheme 1. A base-catalyzed cycloaddition reaction of unsaturated ketones with phenols.

Inspired by Fan's work, we anticipated synthesizing 3-hydroxy-3-(trifluoromethyl)-2a,10c-dihydro$2 \mathrm{H}, 3 \mathrm{H}$-benzo[f]chromeno[3,4-c]chromen-2-one (A) first and then 3-(trifluoromethyl)-2H,10cHbenzo[f]chromeno[3,4-c]chromen-2-one (B) by using coumarins containing $\mathrm{CF}_{3}(\mathbf{1 a})$ and 2-naphthol as starting materials in a preliminary experiment (Scheme 2). However, we did not obtain the expected products (A and B). Two new dihydrocoumarin derivatives, 1-(2-hydroxyphenyl)-3-oxo-2-(2,2,2trifluoroacetyl)-2,3-dihydro-1H-benzo[f]chromen-2-ide (C) and 2-hydroxy-2-(trifluoromethyl)-2a,10cdihydro-2H,3H-benzo[f]chromeno[3,4-c]chromen-3-one (3a), were unexpectedly synthesized instead.

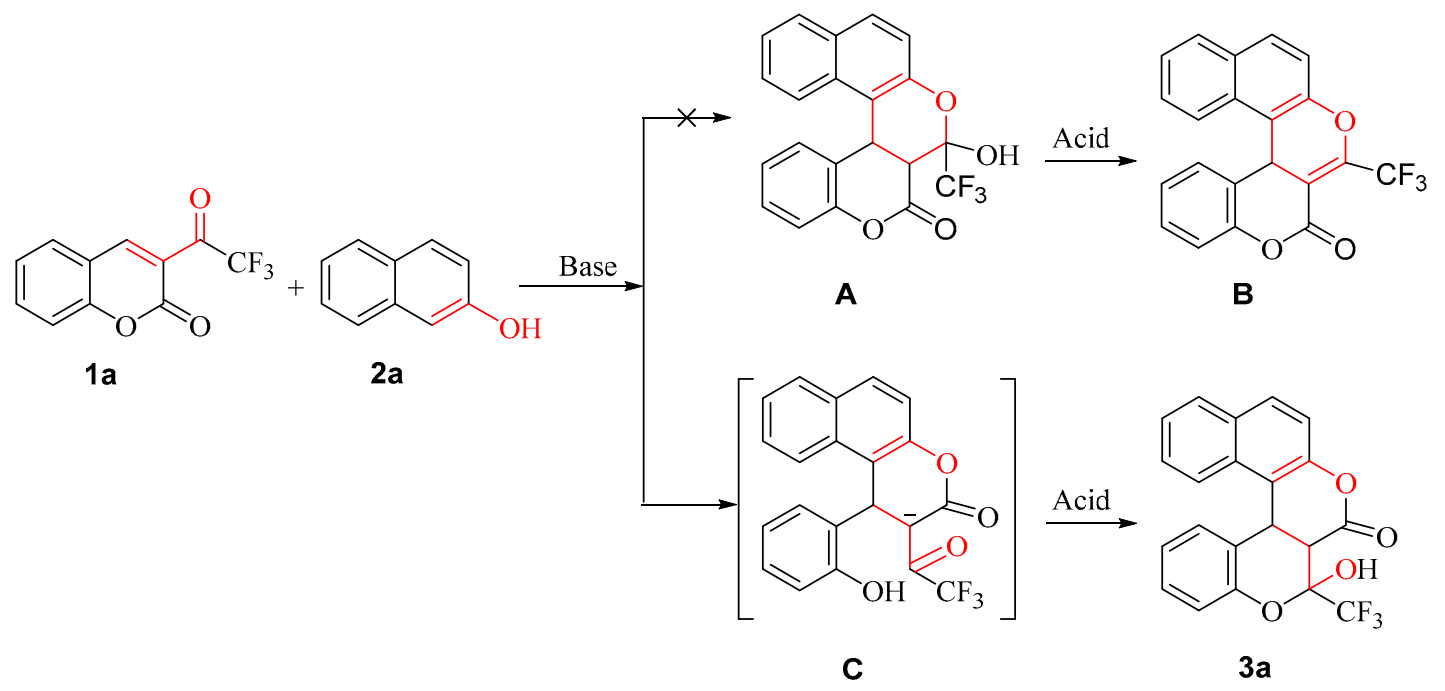

Scheme 2. Synthesis of 3-(trifluoroacetyl)coumarin with 2-naphthol.

Dihydrocoumarin is an important core structure of many bioactive compounds. For example, the derivatives of dihydrocoumarin have dual physiological activities in plants and various pharmacological effects on the human body, such as antioxidant, antiviral and antibacterial effects $[26,27]$. Therefore, 
it is necessary to explore whether this reaction can be developed into a new method for the preparation of dihydrocoumarin derivatives.

We initiated the model reaction of 3-(trifluoroacetyl)coumarin (1a) with 2-naphthol (2a) to establish optimal reaction conditions. The results of the optimization were presented in Table 1.

Table 1. The screening of catalysts and acidifiers ${ }^{a}$.

\begin{tabular}{|c|c|c|c|c|}
\hline Entry & Base & Acid & $t(h)$ & Yield $^{\mathrm{b}}(\%)$ \\
\hline 1 & $\mathrm{i}-\mathrm{Pr}_{2} \mathrm{NEt}$ & $\mathrm{HCl}$ & 2 & 85 \\
\hline 2 & $\mathrm{NEt}_{3}$ & $\mathrm{HCl}$ & 2 & 85 \\
\hline 3 & DBU & $\mathrm{HCl}$ & 2 & 80 \\
\hline 4 & DMAP & $\mathrm{HCl}$ & 2 & 4 \\
\hline 5 & NMI & $\mathrm{HCl}$ & 2 & 3 \\
\hline 6 & Py & $\mathrm{HCl}$ & 2 & trace \\
\hline 7 & NMM & $\mathrm{HCl}$ & 2 & 62 \\
\hline 8 & TMEDA & $\mathrm{HCl}$ & 2 & 29 \\
\hline 9 & DABCO & $\mathrm{HCl}$ & 2 & 13 \\
\hline 10 & $\mathrm{~K}_{2} \mathrm{CO}_{3}$ & $\mathrm{HCl}$ & 2 & trace \\
\hline 11 & $\mathrm{~K}_{2} \mathrm{CO}_{3}+\mathrm{TEBA}$ & $\mathrm{HCl}$ & 2 & 24 \\
\hline 12 & $\mathrm{KF}$ & $\mathrm{HCl}$ & 2 & 8 \\
\hline 13 & $\mathrm{NEt}_{3}$ & Conc. $\mathrm{H}_{2} \mathrm{SO}_{4}$ & 2 & 85 \\
\hline 14 & $\mathrm{NEt}_{3}$ & TFA & 2 & 74 \\
\hline 15 & $\mathrm{NEt}_{3}$ & $p$-TsOH & 2 & 20 \\
\hline 16 & $\mathrm{NEt}_{3}$ & Citric acid & 2 & 38 \\
\hline 17 & $\mathrm{NEt}_{3}$ & Conc. $\mathrm{H}_{2} \mathrm{SO}_{4}$ & DCE & 78 \\
\hline 18 & $\mathrm{NEt}_{3}$ & Conc. $\mathrm{H}_{2} \mathrm{SO}_{4}$ & THF & 24 \\
\hline 19 & $\mathrm{NEt}_{3}$ & Conc. $\mathrm{H}_{2} \mathrm{SO}_{4}$ & $\mathrm{CHCl}_{3}$ & 7 \\
\hline 20 & $\mathrm{NEt}_{3}$ & Conc. $\mathrm{H}_{2} \mathrm{SO}_{4}$ & dioxane & 3 \\
\hline $21^{c}$ & $\mathrm{NEt}_{3}$ & Conc. $\mathrm{H}_{2} \mathrm{SO}_{4}$ & $\mathrm{CH}_{3} \mathrm{CN}$ & 85 \\
\hline $22^{d}$ & $\mathrm{NEt}_{3}$ & Conc. $\mathrm{H}_{2} \mathrm{SO}_{4}$ & $\mathrm{CH}_{3} \mathrm{CN}$ & 65 \\
\hline $23^{\mathrm{e}}$ & $\mathrm{NEt}_{3}$ & Conc. $\mathrm{H}_{2} \mathrm{SO}_{4}$ & $\mathrm{CH}_{3} \mathrm{CN}$ & 71 \\
\hline $24^{\mathrm{c}, \mathrm{f}}$ & $\mathrm{NEt}_{3}$ & Conc. $\mathrm{H}_{2} \mathrm{SO}_{4}$ & $\mathrm{CH}_{3} \mathrm{CN}$ & 86 \\
\hline $25^{c, g}$ & $\mathrm{NEt}_{3}$ & Conc. $\mathrm{H}_{2} \mathrm{SO}_{4}$ & $\mathrm{CH}_{3} \mathrm{CN}$ & 87 \\
\hline $26^{\mathrm{c}, \mathrm{h}}$ & $\mathrm{NEt}_{3}$ & Conc. $\mathrm{H}_{2} \mathrm{SO}_{4}$ & $\mathrm{CH}_{3} \mathrm{CN}$ & 87 \\
\hline $27^{\mathrm{c}, \mathrm{i}}$ & $\mathrm{NEt}_{3}$ & Conc. $\mathrm{H}_{2} \mathrm{SO}_{4}$ & $\mathrm{CH}_{3} \mathrm{CN}$ & 89 \\
\hline $28^{c, j}$ & $\mathrm{NEt}_{3}$ & Conc. $\mathrm{H}_{2} \mathrm{SO}_{4}$ & $\mathrm{CH}_{3} \mathrm{CN}$ & 93 \\
\hline $29^{c, k}$ & $\mathrm{NEt}_{3}$ & Conc. $\mathrm{H}_{2} \mathrm{SO}_{4}$ & $\mathrm{CH}_{3} \mathrm{CN}$ & 92 \\
\hline
\end{tabular}

a Reaction conditions: 1a $(0.50 \mathrm{mmol}), \mathbf{2 a}(0.50 \mathrm{mmol})$, catalyst $(0.50 \mathrm{mmol})$, acidifier $(0.60 \mathrm{mmol})$ and dichloromethane $(5 \mathrm{~mL}), 45^{\circ} \mathrm{C}, 2 \mathrm{~h}$, sealed tube. ${ }^{\mathrm{b}}$ Isolated yields. ${ }^{\mathrm{c}, \mathrm{d} \text {, e }}$ Run at $45^{\circ} \mathrm{C}, 25^{\circ} \mathrm{C}, 65^{\circ} \mathrm{C}{ }^{\mathrm{f}} \mathrm{n}(\mathbf{2 a}): \mathrm{n}(\mathbf{1 a}): \mathrm{n}\left(\mathrm{NEt}_{3}\right)=1: 1.1: 1$. ${ }^{g} \mathrm{n}(\mathbf{2 a}): \mathrm{n}(\mathbf{1 a}): \mathrm{n}\left(\mathrm{NEt}_{3}\right)=1: 1.2: 1 .{ }^{\mathrm{h}} \mathrm{n}(\mathbf{2 a}): \mathrm{n}(\mathbf{1 a}): \mathrm{n}\left(\mathrm{NEt}_{3}\right)=1: 1.3: 1 .{ }^{\mathrm{i}} \mathrm{n}(\mathbf{2 a}): \mathrm{n}(\mathbf{1 a}): \mathrm{n}\left(\mathrm{NEt}_{3}\right)=1: 1.2: 1.3 .{ }^{\mathrm{j}} \mathrm{n}(\mathbf{2 a}): \mathrm{n}(\mathbf{1 a}): \mathrm{n}\left(\mathrm{NEt}_{3}\right)$ $=1: 1 \cdot 2: 1.4 \cdot{ }^{k} \mathrm{n}(\mathbf{2 a}): \mathrm{n}(\mathbf{1 a}): \mathrm{n}\left(\mathrm{NEt}_{3}\right)=1: 1 \cdot 2: 1.5$.

The reaction proceeded satisfactorily at $45{ }^{\circ} \mathrm{C}$ in dichloromethane (DCM) using $N, N-$ diisopropylethylamine $\left(i-\mathrm{Pr}_{2} \mathrm{NEt}\right)$ or triethylamine $\left(\mathrm{NEt}_{3}\right)$ as a catalyst, resulting in a yield of $85 \%$ (Table 1 , Entries 1 and 2). If the base was changed to a strong base, such as 1,8-diazabicyclo[5.4.0]undec-7-ene (DBU), the yield slightly decreased (80\%) (Table 1, Entry 3). None of the other bases, such as dimethylaminopyridine (DMAP), N-methyl imidazole (NMI), Py, N-methylmorpholine (NMM), tetramethylethylenediamine (TMEDA), 1,4-diazabicyclooctane triethylenediamine (DABCO) and inorganic bases, could produce good yields (Table 1, Entries 4-12). For acidifiers, the results showed that the best yield of $85 \%$ was obtained in the presence of hydrochloric acid or concentrated sulfuric acid (Table 1, Entries 2 and 13).

Further experiment indicated that this reaction was sensitive to solvents. The yield was compared to that in DCM when being carried out in $\mathrm{CH}_{3} \mathrm{CN}$, but dropped significantly when in 1,2-dichloroethane (1,2-DCE), tetrahydrofuran (THF), $\mathrm{CHCl}_{3}$ and dioxane (Table 1, Entries 17-20). Moreover, increasing or lowering the reaction temperature resulted in a decreased yield (Table 1, Entries 21-23) and $45^{\circ} \mathrm{C}$ was identified as the ideal reaction temperature for this reaction. Gratifyingly, when the mole ratio of $\mathbf{2 a}$, 
1a and $\mathrm{NEt}_{3}$ was changed from 1:1:1 to 1:1.2:1.4, the reaction gave the best yield (93\%) of 3a (Table 1, Entries 24-29). Further increasing the ratio of $\mathbf{2 a}, \mathbf{1 a}$ and $\mathrm{NEt}_{3}$ failed to provide a better result.

Sixteen coumarin derivatives, 6a,12b-dihydro-6H,7H-chromeno[3,4-c] chromen-6-ones, were prepared from 3-(trifluoroacetyl)coumarin (1) and phenols or 2-naphthol (2), in the presence of $\mathrm{NEt}_{3}$ as a catalyst and hydrochloric acid as an acidifier (Scheme 3 and Table 2).

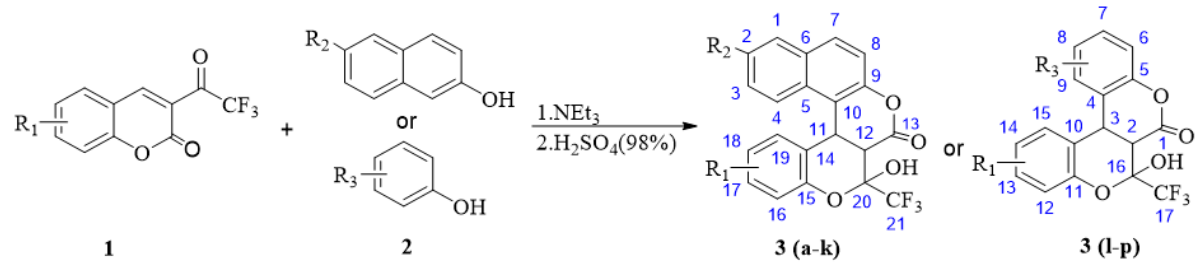

Scheme 3. Synthesis of compounds through reaction of $\mathbf{1}$ and $\mathbf{2}$.

Table 2. Synthesis of compounds 3a-p.

\begin{tabular}{cccccccc}
\hline Entry & $\mathbf{R}_{\mathbf{1}}$ & $\mathbf{R}_{\mathbf{2}}$ & $\mathbf{R}_{\mathbf{3}}$ & $\mathbf{T}\left({ }^{\circ} \mathbf{C}\right)$ & $\mathbf{t} / \mathbf{h}$ & Product $^{\mathbf{a}}$ & Yield $^{\mathbf{b}} \mathbf{( \% )}$ \\
\hline 1 & $\mathrm{H}$ & $\mathrm{H}$ & - & 45 & 1.5 & $\mathbf{3 a}$ & 93 \\
2 & $8-\mathrm{OCH} \mathrm{H}_{3}$ & $\mathrm{H}$ & - & 45 & 0.3 & $\mathbf{3 b}$ & 90 \\
3 & $7-\mathrm{OCH}_{3}$ & $\mathrm{H}$ & - & 45 & 1.5 & $\mathbf{3 c}$ & 94 \\
4 & $6-\mathrm{CH}_{3}$ & $\mathrm{H}$ & - & 45 & 1.5 & $\mathbf{3 d}$ & 91 \\
5 & $6-\mathrm{Br}$ & $\mathrm{H}$ & - & 45 & 0.5 & $\mathbf{3 e}$ & 92 \\
6 & $\mathrm{H}$ & $\mathrm{Br}$ & - & 45 & 1.5 & $\mathbf{3 f}$ & 94 \\
7 & $8-\mathrm{OCH} \mathrm{H}_{3}$ & $\mathrm{Br}$ & - & 45 & 1 & $\mathbf{3 g}$ & 89 \\
8 & $7-\mathrm{OCH} 3$ & $\mathrm{Br}$ & - & 45 & 1 & $\mathbf{3 h}$ & 90 \\
9 & $6-\mathrm{Cl}$ & $\mathrm{Br}$ & - & 45 & 1 & $3 \mathbf{i}$ & 91 \\
10 & $\mathrm{H}$ & $\mathrm{CN}$ & - & 45 & 2 & $3 \mathbf{j}$ & 88 \\
11 & $7-\mathrm{OCH} H_{3}$ & $\mathrm{CN}$ & - & 45 & 2 & $3 \mathbf{3}$ & 89 \\
$12^{\mathrm{c}}$ & $\mathrm{H}$ & - & $\mathrm{H}$ & 65 & 5 & $3 \mathbf{1}$ & 65 \\
$13^{\mathrm{c}}$ & $\mathrm{H}$ & - & $3-\mathrm{OH}$ & 65 & 3 & $\mathbf{3 m}$ & 74 \\
$14^{\mathrm{c}}$ & $8-\mathrm{OCH} \mathrm{H}_{3}$ & - & $4-\mathrm{OH}$ & 65 & 6 & $\mathbf{3 n}$ & 80 \\
$15^{\mathrm{c}}$ & $6-\mathrm{Cl}$ & - & $4-\mathrm{OH}$ & 65 & 4 & $\mathbf{3 o}$ & 82 \\
$16^{\mathrm{c}}$ & $\mathrm{H}$ & - & $3-\mathrm{OH}, 5-\mathrm{CH}_{3}$ & 65 & 6 & $\mathbf{3 p}$ & 87 \\
\hline
\end{tabular}

a Reaction conditions: 1a $(0.64 \mathrm{mmol}), \mathbf{2 a}(0.50 \mathrm{mmol})$ and $\mathrm{NEt}_{3}(0.71 \mathrm{mmol})$ carried out in a pressure vial at $45^{\circ} \mathrm{C}$ by high-performance liquid chromatography (HPLC) tracking. ${ }^{b}$ Yield of isolated product. ${ }^{c}$ Run at $65^{\circ} \mathrm{C}$.

As seen from Table 2, a variety of coumarins bearing either electron-withdrawing or electron-donating groups on the aryl ring could be transformed into the corresponding novel dihydrocoumarin compounds with $\mathrm{CF}_{3}, 3 \mathbf{a}-\mathbf{p}$, with good to excellent yields (65-94\%) by this simple procedure (Scheme 3). The reactions between coumarins $\mathbf{1}$ and 2-naphthols proceeded smoothly in most cases to give the products $3 \mathbf{a}-\mathbf{k}$ at a relatively lower temperature $\left(45^{\circ} \mathrm{C}\right)$ in a short time $(0.3-2 \mathrm{~h})$ (Entries 1-11). However, the reactions of coumarins 1 with phenols required a higher temperature $\left(65^{\circ} \mathrm{C}\right)$ and longer time (3-6 h) for a lower yield, below 90\% (Entries 13-16). From this point of view, the electronic density of 2-naphthols was crucial for this reaction, and the electron-donating group on the naphthalene ring was favorable to the reaction rate and yield. Indeed, the yields decreased slightly in the case of strong electron-withdrawing groups, such as $\mathrm{CN}$, on the naphthalene ring, and a slightly longer reaction time of $2 \mathrm{~h}$ was needed (Entries 10 and 11). The results were similar for the reactions between coumarins 1 and phenols. It was not until there were strong electron-donating groups, such as $\mathrm{OH}$, on the phenol ring that the reactions could run smoothly at a higher temperature $\left(65^{\circ} \mathrm{C}\right)$ and longer times of 3-6 h (Entries 12-16).

\subsection{Structural Characterization of Chromenes 3a-p}

The structures of the synthesized compounds were confirmed by ${ }^{1} \mathrm{H}-\mathrm{NMR},{ }^{13} \mathrm{C}-\mathrm{NMR}, \mathrm{IR}$, and HRMS. For example, the ${ }^{1} \mathrm{H}-\mathrm{NMR}$ spectrum of 3 a showed two doublet signals for $\mathrm{CH}$ at $3.72 \mathrm{ppm}$ and 
$5.26 \mathrm{ppm}$, respectively, a broad singlet signal for $\mathrm{OH}$ at $7.48 \mathrm{ppm}$ and a multiplet signal at 6.59-8.06 ppm for aromatic protons. The downfield shift in the signal of two protons at the 3- and 4-positions, which appeared at $3.0 \mathrm{ppm}$ and $4.2 \mathrm{ppm}$, respectively, in reported 3,4-dihydrocoumarins [13], was caused by the inductive effects of neighboring $\mathrm{OH}$ and $\mathrm{CF}_{3}$ groups. The decoupled ${ }^{13} \mathrm{C}-\mathrm{NMR}$ spectrum of $3 \mathbf{a}$ showed 17 distinct resonance structures, in agreement with the proposed structure. Among them, the two quartet signals for $\mathrm{C}-\mathrm{CF}_{3}$ at $95.71 \mathrm{ppm}$ and $\mathrm{CF}_{3}$ at $122.13 \mathrm{ppm}$ for which ${ }^{2} \mathrm{~J}_{\mathrm{C}, \mathrm{F}}=33 \mathrm{~Hz}$ and ${ }^{1} J_{\mathrm{C}, \mathrm{F}}=$ $286 \mathrm{~Hz}$, respectively, were observed. The IR spectrum of $\mathbf{3 a}$ displayed characteristic $\mathrm{OH}, \mathrm{C}=\mathrm{O}$ and $\mathrm{C}-\mathrm{F}$ vibrations at 3419,1728 and $822 \mathrm{~cm}^{-1}$, respectively. The HRMS data for $3 a$ showed the molecular ion peak at $m / z[\mathrm{M}-\mathrm{H}]^{+}$was 385.0688, consistent with the calculated value of 385.0688 .

By cooling the solutions of $\mathbf{3 a}$ and $\mathbf{3 n}$ in ethyl acetate, single crystals suitable for X-ray crystallographic analysis were obtained, and their crystal structures are shown in Figure 1. Compound 3a has a twisted conformation. Its benzene ring and naphthalene ring are connected by the sp3 carbon atom of $\mathrm{C} 11$ with a $\mathrm{C} 10-\mathrm{C} 11-\mathrm{C} 14$ angle of $115.01(16)^{\circ}$, and a dihedral angle of $72.776^{\circ}$ between the benzene ring and the naphthalene ring is observed. Interestingly, the rotation of the chiral carbon atoms of $\mathrm{C} 11$ and $\mathrm{C} 12$ are restricted by intramolecular hydrogen bonding between $\mathrm{H}$ on $\mathrm{C} 12$ and C11 and $\mathrm{F}$ in trifluoromethyl groups, with $\mathrm{CH} \cdots \mathrm{F}$ distances of 2.519 and $2.344 \AA$, respectively. Moreover, the adjacent molecules are connected by intermolecular hydrogen bonding with a distance of $2.610 \AA$, which is almost equal to the van der Waals radius (2.6 $\AA$ ) [28]. In comparison to 3a, 3n also has a twisted conformation. However, two benzene rings are almost perpendicular to each other with a dihedral angle of $89.045^{\circ}$, and the C4-C3-C10 angle of $113.38(16)^{\circ}$ is slightly narrowed in comparison to that in 3a. In addition, $3 n$ shows weak intermolecular interactions with a centroid distance of $4.126 \AA$ between adjacent methoxy-substituted benzene rings (Figure 1d). Both compounds 3a and 3n exhibit three chiral carbon atoms, $\mathrm{C} 11, \mathrm{C} 12$, and $\mathrm{C} 21$ and $\mathrm{C} 2, \mathrm{C} 3$, and $\mathrm{C} 16$, respectively. The refinement information of compounds $3 \mathbf{a}\left(\mathrm{C}_{21} \mathrm{H}_{13} \mathrm{~F}_{3} \mathrm{O}_{4}\right)$ and $\mathbf{3 n}\left(\mathrm{C}_{18} \mathrm{H}_{13} \mathrm{~F}_{3} \mathrm{O}_{6}\right)$ is summarized in the Supplementary Materials.

(a)

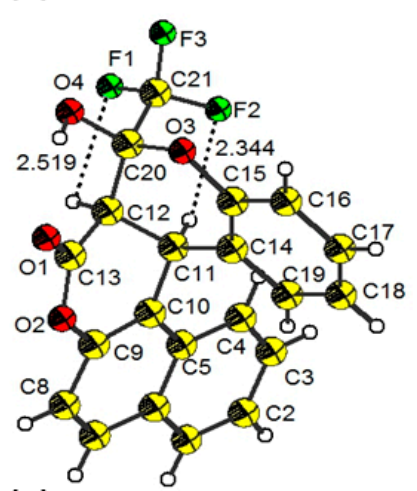

(c)

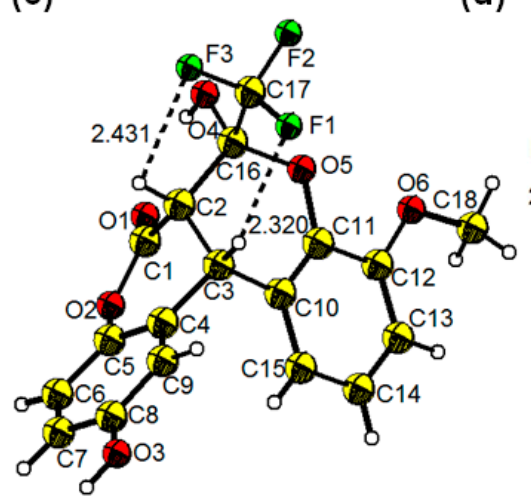

(b)

(d)
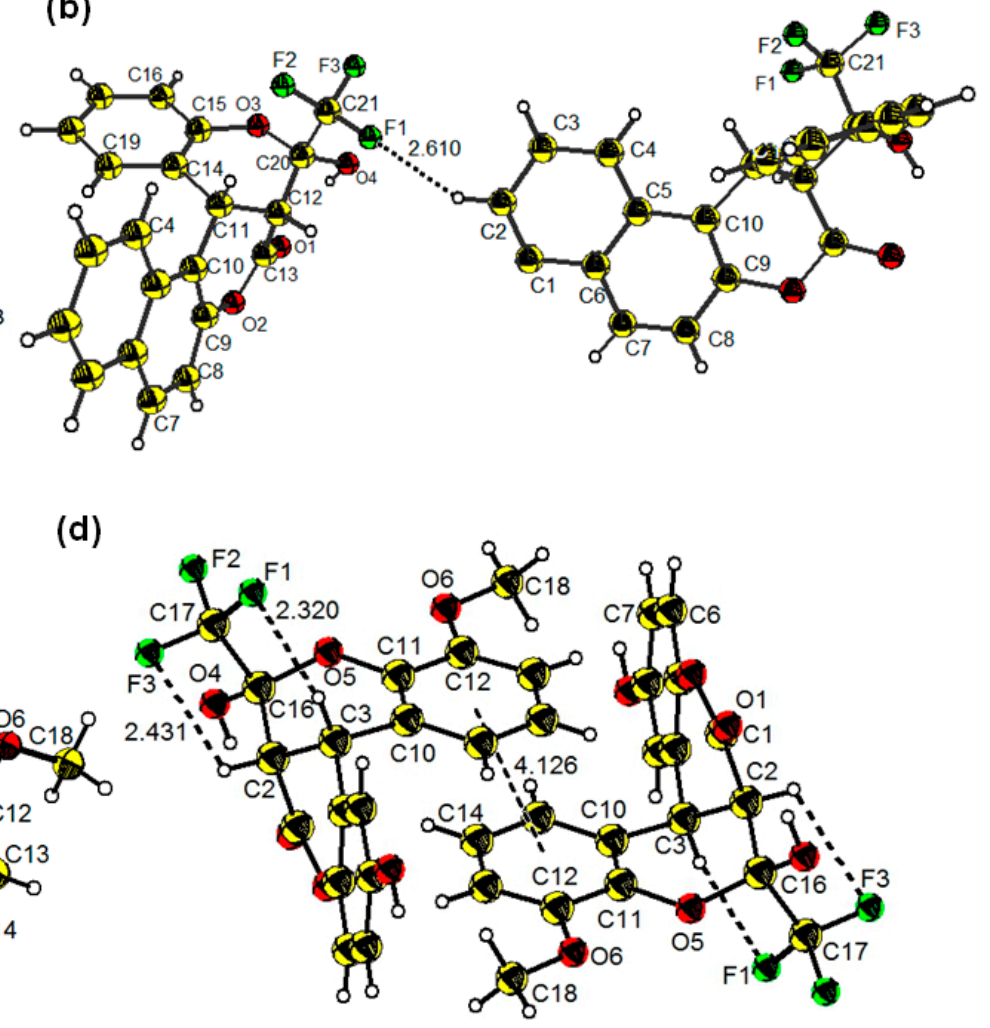

Figure 1. Thermal ellipsoid (30\%) drawings of compound 3a (a); packing of the crystal structure of 3a (b); thermal ellipsoid (30\%) drawings of compound 3n (c); and intermolecular hydrogen bonding of compound 3n (d). Note: yellow, carbon; white, hydrogen; red, oxygen; green, fluorine. 


\subsection{Reaction Mechanism}

To speculate on the mechanism of the reaction, we obtained the crystals of compound 3a before acidification, and it was ammonium salt $\mathbf{3} \mathbf{a}^{\mathbf{1}}$ of compound $\mathbf{3} \mathbf{a}$, being formed from the reaction between $\mathrm{Et}_{3} \mathrm{~N}$ and DCM (Figure 2). Compound 3a exists in an open form with a free carbonyl group attached to $-\mathrm{CF}_{3}$ in the presence of base and easily forms a semiacetal structure with a stable six-membered ring by internal nucleophilic attack of the $\mathrm{OH}$ group to an active $\mathrm{C}=\mathrm{O}$ group after acidification.

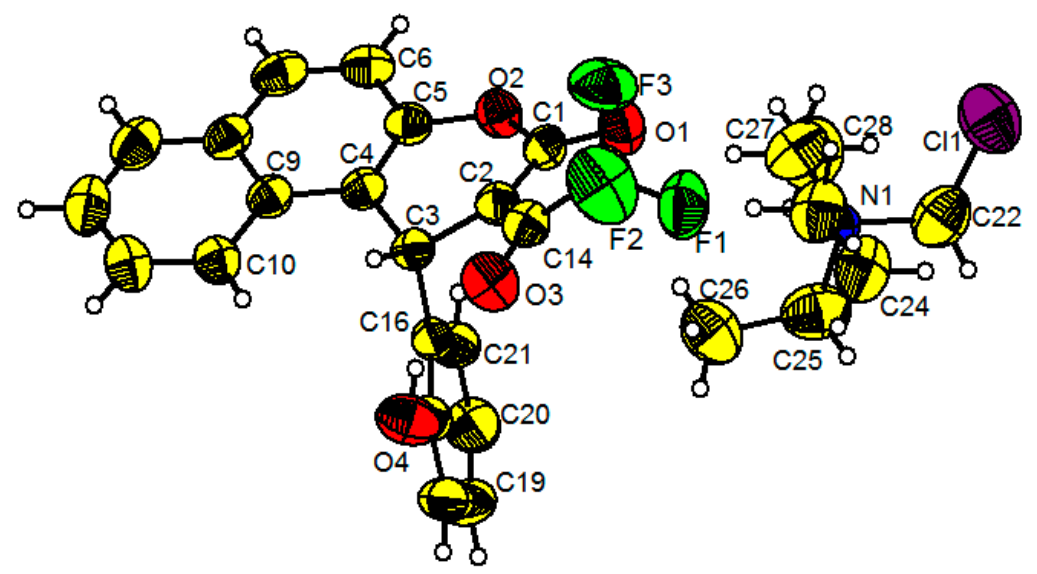

Figure 2. The ammonium salt $\mathbf{3} \mathbf{a}^{\mathbf{1}}$ of compound 3a (CCDC 1900315). Note: yellow, carbon; white, hydrogen; red, oxygen; green, fluorine; blue, nitrogen; purple, chlorine.

Scheme 4 shows plausible pathways for the reaction. First, the 1,4-nucleophilic addition of 2-naphthol (2) to 3-trifluoroacetyl coumarin 1 with an $\alpha, \beta$-unsaturated ketone structure generates the carbon anion intermediate I. It then forms enolate anion II by H-transformation. Intermediate II is next transformed into a new coumarin with phenoxy anion III through nucleophilic attack by a naphthalenyl oxyanion at the initial ester group of coumarin with slightly stronger basicity as the driving force. The subsequent addition of a phenoxy anion to the electrophilic carbon of $-\mathrm{COCF}_{3}$ group happened to furnish annulation product IV, forming the final title compound 3a with a semiacetal structure after acidification.

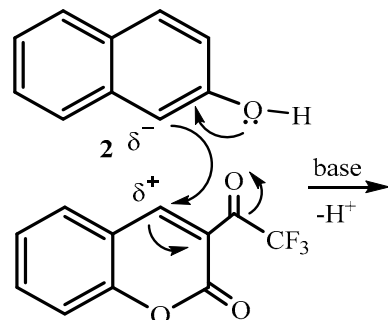

1<smiles>O=C1Oc2ccc3ccccc3c2C2c3ccccc3OC(O)(C(F)(F)F)C12</smiles>

3a<smiles>C=CC(=O)C1C(=O)Oc2ccccc2C1C1C(=O)C=Cc2ccccc21</smiles>

I

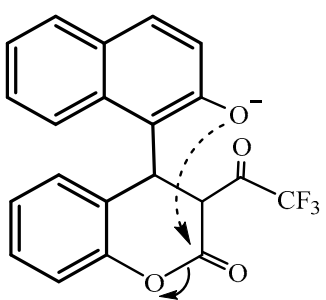

II<smiles>O=C1Oc2ccc3ccccc3c2C2c3ccccc3OC(F)(C(F)(F)F)C12</smiles>

IV<smiles>CCC(C)(C)C1C(=O)Oc2ccc3ccccc3c2C1c1ccccc1O</smiles>

III

Scheme 4. Plausible mechanism for compound 3a. 


\subsection{In Vitro Antifungal Assay}

The antifungal activities of the target compounds $3 \mathbf{a}-\mathbf{p}$ were evaluated against Fusarium graminearum and Fusarium monitiforme by the mycelial growth rate method [29] at $500 \mu \mathrm{g} / \mathrm{mL}$, using triazolone $(100 \mu \mathrm{g} / \mathrm{mL})$ as the positive control. The results of the antifungal activities were shown in Figure 3.

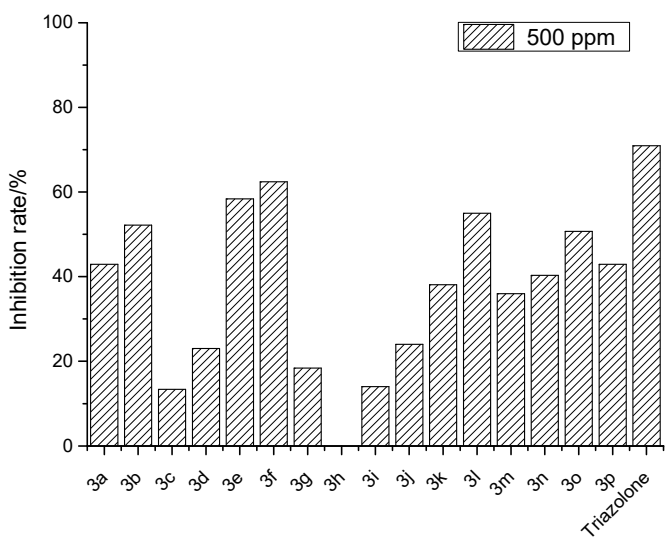

(a)

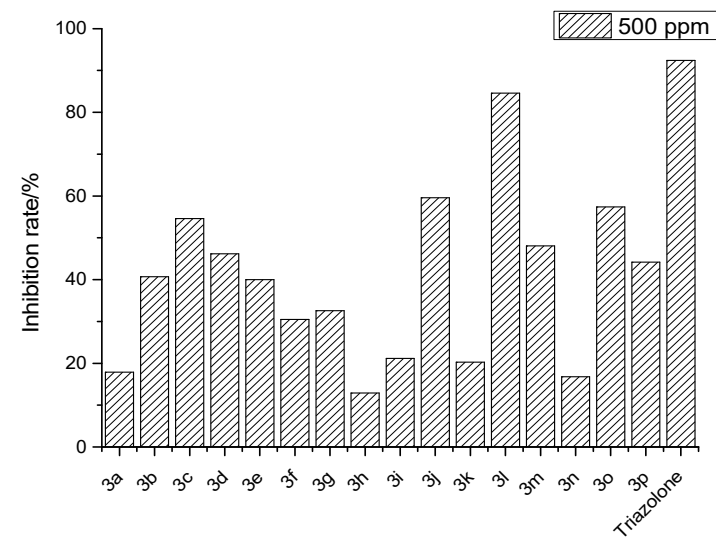

(b)

Figure 3. Antifungal activity of the target compounds 3a-p, against-Fusarium graminearum (a) and Fusarium monitiforme (b).

The bioassay results for Fusarium graminearum indicated that, except for compound $3 h$, all the target compounds showed antifungal activities to some extent, with an inhibitory index in the range of 13.4-62.4\%. The inhibitory index of compounds $3 \mathbf{a}$ and 31 were $42.9 \%$ and $55 \%$, respectively. From the activity results for the derivatives $(\mathbf{3} \mathbf{b}-\mathbf{k})$ of compound $3 \mathbf{a}$ obtained by structure modification, compared with compound $\mathbf{3} \mathbf{a}$, compounds $\mathbf{3} \mathbf{b}, \mathbf{3} \mathbf{e}$ and $\mathbf{3} \mathbf{f}$ showed greater inhibition of F. graminearum, with inhibitory indexes of $52.2 \%, 58.4 \%$ and $62.4 \%$, respectively.

The obtained findings suggested that a functional group, such as bromine, introduced into compound 3a could substantially contribute to the antifungal efficacy of its derivatives. However, the derivatives $(3 \mathbf{m}-\mathbf{p})$ of compound 31 , whether bearing electron-donating or electron-withdrawing groups, all showed lower antifungal activities against $F$. graminearum than that of compound 31.

Moreover, the inhibitory index of compound 31 against $F$. monitiforme (84.6\%) was much higher than that of compound $3 \mathbf{a}(17.9 \%)$, which indicated that compared with the benzene ring, the naphthalene ring at the 4-position of dihydrocoumarin is unfavorable for activity against $F$. monitiforme. However, the compounds $\mathbf{3} \mathbf{b}-\mathbf{k}$ modified from compound $\mathbf{3 a}$, except compound $\mathbf{3 h}$, all had higher antifungal activities against $F$. monitiforme (inhibitory index: 21.2-59.6\%) than compound 3a. The reason may be that the introduction of a functional group can increase the antifungal activity. Similar to the antifungal results against $F$. graminearum, the compounds $(3 \mathbf{m}-\mathbf{p})$ modified from compound 31 all showed lower antifungal activities against $F$. monitiforme (inhibitory index: $16.8 \%-57.4 \%$ ) than compound 31. Further research about structure and activity is in progress.

\section{Materials and Methods}

\subsection{General Information}

HPLC analyses were performed with Thermo Fisher U-3000 (Chromatographic column: XDB-C 18 column with $\mathrm{MeOH}-\mathrm{H}_{2} \mathrm{O}$ as the eluent, (Thermo Fisher scientific Co., Waltham, MA, USA) equipped with an UltiMate 3000UV detector (Thermo Fisher scientific Co., Waltham, MA, USA). Melting points were determined on an X-5 digital microscopic melting-point apparatus (Beijing Tech Instruments Co., Beijing, China) and were uncorrected. High resolution mass spectra were obtained using a Waters 
Q-Tof MicroTM instrument (Waters Co., MA, USA). NMR spectra were recorded on a Bruker DPX-400 spectrometer (Bruker Optics Co., Ettlingen, baden-wuerttemberg, Germany) in dimethyl sulfoxide$d_{6}$ (DMSO- $\left.d_{6}\right)$ or chloroform-D $\left(\mathrm{CDCl}_{3}\right)$ using tetramethylsilane as the internal standard. Chemical shifts $(\delta)$ were reported in ppm, and $J$ values were reported in Hertz. The IR spectra were recorded on a Thermo IS10 FT-IR spectrometer (Thermo scientific Co., Shenzhen, Guangdong, China), and the frequencies were reported in $\mathrm{cm}^{-1}$. X-ray images were obtained with a Rigaku RAXIAS-IV type diffractometer (Rigaku Corporation Co., Tokyo, Japan).

The starting materials (1) were obtained according to the reported procedure [30]. All other reagents were acquired from commercial sources and utilized without further purification.

\subsection{General Synthetic Procedures for Compounds 3a-p}

Typical procedure for the synthesis of compound 3a: compound $1(0.64 \mathrm{mmol})$, naphthol $(0.50 \mathrm{mmol}), \mathrm{NEt}_{3}(0.71 \mathrm{mmol})$ and $5 \mathrm{~mL} \mathrm{CH}_{3} \mathrm{CN}$ were added to a pressure vial. The reaction mixture was stirred at $45^{\circ} \mathrm{C}$ for $1.5 \mathrm{~h}$ (HPLC tracking reaction), and then cooled down to room temperature. After the addition of concentrated $\mathrm{H}_{2} \mathrm{SO}_{4}(0.71 \mathrm{mmol})$, the resulting mixture was stirred at room temperature for $2 \mathrm{~h}$. The crude reaction mixture was concentrated by rotary evaporator, and dissoloved in DCM $30 \mathrm{~mL}$. Then it was washed with water $(15 \mathrm{~mL} \times 3)$ and the organic layers were dried with $\mathrm{Na}_{2} \mathrm{SO}_{4}$, filtered, and concentrated in vacuo. A white crystal was obtained after crystallization from ethyl acetate-petroleum ether $(0.183 \mathrm{~g}, 93 \%)$.

\subsection{Biological Assays}

The antifungal activity of synthesized compounds $\mathbf{3 a}-\mathbf{p}$ was tested against two pathogenic fungi, namely, Fusarium graminearum and Fusarium monitiforme, by the poison plate technique at a concentration of $500 \mu \mathrm{g} / \mathrm{mL}$. The two species of fungi were incubated in potato dextrose agar medium at $25 \pm 1{ }^{\circ} \mathrm{C}$ for five days to obtain new mycelia for the antifungal assay, and then mycelia as disks of approximately $0.70 \mathrm{~cm}$ diameter cut from the culture medium were picked up with a sterilized inoculation needle and inoculated into the center of a PDA plate. The test compounds were dissolved in dimethyl sulfoxide $(1 \mathrm{~mL})$ then diluted to a $7500 \mu \mathrm{g} / \mathrm{mL}$ drug solution with $4 \%$ tween- 80 emulsifier $(1 \mathrm{~mL})$ and added to the PDA medium $(30 \mathrm{~mL})$. The final concentration of compounds in the medium was adjusted to $500 \mu \mathrm{g} / \mathrm{mL}$. The inoculated plates were incubated at $25 \pm 1{ }^{\circ} \mathrm{C}$ for 3 days. Dimethyl sulfoxide was diluted with sterilized distilled water (4\% tween- 80$)$ and used as the control, while the commercial fungicide triazolone $(100 \mu \mathrm{g} / \mathrm{mL})$ was used as the standard control. Three replicates of the experiments were performed. The radial growth of the fungal colonies was measured on the fourth day.

2-Hydroxy-2-(trifluoromethyl)-2a,10c-dihydro-2H,3H-benzo[f]chromeno[3,4-c]chromen-3-one Crystallization from ethyl acetate-petroleum ether, white crystal; M.p. $172.6 \sim 173.7{ }^{\circ} \mathrm{C} ;{ }^{1} \mathrm{H}-\mathrm{NMR}$ $\left(\mathrm{CDCl}_{3}, 400 \mathrm{MHz}\right) \delta: 3.72(\mathrm{~d}, J=4 \mathrm{~Hz}, 1 \mathrm{H}, \mathrm{CH}), 5.26(\mathrm{~d}, J=4 \mathrm{~Hz}, 1 \mathrm{H}, \mathrm{CH}), 6.59(\mathrm{~d}, J=4 \mathrm{~Hz}, 1 \mathrm{H}, \mathrm{Ar}-\mathrm{H})$, $6.70\left(\mathrm{td}, J_{1}=8 \mathrm{~Hz}, J_{2}=1.2 \mathrm{~Hz}, \operatorname{Ar}-\mathrm{H}\right), 7.12(\mathrm{q}, J=4 \mathrm{~Hz}, 1 \mathrm{H}, \mathrm{Ar}-\mathrm{H}), 7.23 \sim 7.33(\mathrm{~m}, 2 \mathrm{H}, \mathrm{Ar}-\mathrm{H}), 7.48(\mathrm{~s}, 1 \mathrm{H}$, $-\mathrm{OH}), 7.64\left(\mathrm{td}, J_{1}=8 \mathrm{~Hz}, J_{2}=0.8 \mathrm{~Hz}, 1 \mathrm{H}, \mathrm{Ar}-\mathrm{H}\right), 7.74\left(\mathrm{td}, J_{1}=8 \mathrm{~Hz}, J_{2}=1.2 \mathrm{~Hz}, 2 \mathrm{H}, \mathrm{Ar}-\mathrm{H}\right), 7.98 \sim 8.06(\mathrm{~m}$, 3H, Ar-H); ${ }^{13} \mathrm{C}-\mathrm{NMR}\left(100 \mathrm{MHz}, \mathrm{CDCl}_{3}\right) \delta: 31.12$ (q, $\left.J=3 \mathrm{~Hz}, \mathrm{C} 1\right), 39.46$ (C1), 95.71 (q, J = 33 Hz, C20), 116.24 (C16), 116.94 (C18), 117.60 (C8), 118.29 (C10), 122.13 (q, J = 286 Hz, C21), 122.64 (C4), 122.90 (C2), 126.20 (C3), 127.61 (C17), 128.61 (C7), 129.13 (C1), 129.92 (C19), 130.88 (C6), 131.33 (C14), 131.82 (C5), 147.44 (C9), 152.64 (C15), 168.35 (C13); IR (KBr) $v_{\max }\left(\mathrm{cm}^{-1}\right)$ : $3419(\mathrm{OH}), 1728$ (C=O), 1585 (Ar), 822 $\left(\mathrm{CF}_{3}\right)$; HRMS (ESI): $\mathrm{m} / z$ calcd for $\mathrm{C}_{21} \mathrm{H}_{12} \mathrm{~F}_{3} \mathrm{O}_{4}[\mathrm{M}-\mathrm{H}]^{+}:$385.0688; found: 385.0688.

2-Hydroxy-14-methoxy-2-(trifluoromethyl)-2a,10c-dihydro-2H,3H-benzo[f]chromeno[3,4-c]chromen-3-one (3b): Crystallization from ethyl acetate-petroleum ether, white crystal; M.p. $173.7 \sim 174.5{ }^{\circ} \mathrm{C} ;{ }^{1} \mathrm{H}-\mathrm{NMR}$ $\left(\mathrm{CDCl}_{3}, 400 \mathrm{MHz}\right) \delta: 3.67(\mathrm{~d}, J=4 \mathrm{~Hz}, 1 \mathrm{H}, \mathrm{CH}), 3.88\left(\mathrm{~s}, 3 \mathrm{H}, \mathrm{CH}_{3}\right), 5.22(\mathrm{~d}, J=4 \mathrm{~Hz}, 1 \mathrm{H}, \mathrm{CH}), 6.13(\mathrm{~d}, J=$ $4 \mathrm{~Hz}, 1 \mathrm{H}, \mathrm{Ar}-\mathrm{H}), 6.68(\mathrm{t}, J=8 \mathrm{~Hz}, 1 \mathrm{H}, \mathrm{Ar}-\mathrm{H}), 6.81(\mathrm{~d}, J=8 \mathrm{~Hz}, 1 \mathrm{H}, \mathrm{Ar}-\mathrm{H}), 7.27(\mathrm{~d}, J=4 \mathrm{~Hz}, 1 \mathrm{H}, \mathrm{Ar}-\mathrm{H})$, $7.47(\mathrm{~s}, 1 \mathrm{H},-\mathrm{OH}), 7.58\left(\mathrm{td}, J_{1}=8 \mathrm{~Hz}, J_{2}=0.8 \mathrm{~Hz}, 1 \mathrm{H}, \mathrm{Ar}-\mathrm{H}\right), 7.68\left(\mathrm{td}, J_{1}=8 \mathrm{~Hz}, J_{2}=0.8 \mathrm{~Hz}, 1 \mathrm{H}, \mathrm{Ar}-\mathrm{H}\right)$, 
7.92 8.00 (m, 3H, Ar-H); ${ }^{13} \mathrm{C}-\mathrm{NMR}\left(100 \mathrm{MHz}, \mathrm{CDCl}_{3}\right)$ ): 31.16 (q, J = $\left.2 \mathrm{~Hz}, \mathrm{C} 11\right), 39.38$ (C12), 56.30 $\left(-\mathrm{OCH}_{3}\right), 95.97$ (q, J = 26 Hz, C20), 112.34 (C17), 116.29 (C19), 116.87 (C18), 118.92 (C8), 119.40 (C10), 122.08 (q, J = 229 Hz, C21), 122.20 (C4), 122.90 (C2), 126.10 (C3), 128.49 (C7), 129.04 (C1), 130.79 (C6), 131.27 (C14), 131.73 (C5), 142.31 (C16), 147.41 (C15), 148.65 (C9), 168.26 (C13); IR (KBr) $v_{\max }\left(\mathrm{cm}^{-1}\right)$ : $3391(\mathrm{OH}), 1736(\mathrm{C}=\mathrm{O}), 1582,1478(\mathrm{Ar}), 817\left(\mathrm{CF}_{3}\right)$; HRMS (ESI): $\mathrm{m} / z$ calcd for $\mathrm{C}_{22} \mathrm{H}_{15} \mathrm{~F}_{3} \mathrm{O}_{5}[\mathrm{M}-\mathrm{H}]^{+}$: 415.0793; found: 415.0795 .

2-Hydroxy-13-methoxy-2-(trifluoromethyl)-2a,10c-dihydro-2H,3H-benzo[f]chromeno[3,4-c]chromen-3-one (3c): Crystallization from ethyl acetate-petroleum ether, white crystal; M.p. $173.6 \sim 174.3{ }^{\circ} \mathrm{C} ;{ }^{1} \mathrm{H}-\mathrm{NMR}$ $\left(\mathrm{CDCl}_{3}, 400 \mathrm{MHz}\right) \delta: 3.64(\mathrm{~d}, J=4 \mathrm{~Hz}, 1 \mathrm{H}, \mathrm{CH}), 3.72\left(\mathrm{~s}, 3 \mathrm{H}, \mathrm{CH}_{3}\right), 5.14(\mathrm{~d}, J=4 \mathrm{~Hz}, 1 \mathrm{H}, \mathrm{CH}), 6.31(\mathrm{dd}$, $\left.J_{1}=8 \mathrm{~Hz}, J_{2}=2 \mathrm{~Hz}, 1 \mathrm{H}, \mathrm{Ar}-\mathrm{H}\right), 6.42\left(\mathrm{dd}, J_{1}=4 \mathrm{~Hz}, J_{2}=0.8 \mathrm{~Hz}, 1 \mathrm{H}, \mathrm{Ar}-\mathrm{H}\right), 6.62(\mathrm{~d}, J=4 \mathrm{~Hz}, 1 \mathrm{H}, \mathrm{Ar}-\mathrm{H})$, $7.69\left(\mathrm{td}, J_{1}=8 \mathrm{~Hz}, J_{2}=0.8 \mathrm{~Hz}, 1 \mathrm{H}, \mathrm{Ar}-\mathrm{H}\right), 7.92 \sim 8.00(\mathrm{~m}, 3 \mathrm{H}, \mathrm{Ar}-\mathrm{H}) ;{ }^{13} \mathrm{C}-\mathrm{NMR}\left(100 \mathrm{MHz}, \mathrm{CDCl}_{3}\right) \delta$ : $30.59(\mathrm{q}, J=3 \mathrm{~Hz}, \mathrm{C} 11), 39.64(\mathrm{C} 12), 55.39\left(-\mathrm{OCH}_{3}\right), 95.79(\mathrm{q}, J=26 \mathrm{~Hz}, \mathrm{C} 20), 102.11$ (C16), 109.75 (C18), 110.00 (C8), 116.38 (C14), 116.90 (C10), 122.05 (q, J = 229 Hz, C21), 122.87 (C4), 126.11 (C2), 128.25 (C3), 128.51 (C7), 129.06 (C1), 130.64 (C19), 131.29 (C6), 131.76 (C5), 147.28 (C9), 153.55 (C15), 160.87 (C17), 168.41 (C13); IR (KBr) $v_{\max }\left(\mathrm{cm}^{-1}\right): 3402(\mathrm{OH}), 1736(\mathrm{C}=\mathrm{O}), 1628,1501(\mathrm{Ar}), 819\left(\mathrm{CF}_{3}\right) ; \mathrm{HRMS}(\mathrm{ESI}): \mathrm{m} / z$ calcd for $\mathrm{C}_{22} \mathrm{H}_{15} \mathrm{~F}_{3} \mathrm{O}_{5}[\mathrm{M}-\mathrm{H}]^{+}$: 415.0793; found: 415.0792 .

2-Hydroxy-12-methyl-2-(trifluoromethyl)-2a,10c-dihydro-2H,3H-benzo[f]chromeno[3,4-c]chromen-3-one (3d): Crystallization from ethyl acetate-petroleum ether, white crystal; M.p. 160.2 161.1 ${ }^{\circ} \mathrm{C} ;{ }^{1} \mathrm{H}-\mathrm{NMR}$ (DMSO- $\left.d_{6}, 400 \mathrm{MHz}\right) \delta: 1.97\left(\mathrm{~s}, 3 \mathrm{H}, \mathrm{CH}_{3}\right), 3.61\left(\mathrm{dd}, J_{1}=6 \mathrm{~Hz}, J_{2}=1.2 \mathrm{~Hz}, 1 \mathrm{H}, \mathrm{CH}\right), 5.60(\mathrm{~d}, J=6 \mathrm{~Hz}$, $1 \mathrm{H}, \mathrm{CH}), 6.17(\mathrm{~s}, 1 \mathrm{H}, \mathrm{Ar}-\mathrm{H}), 7.02(\mathrm{q}, J=8 \mathrm{~Hz}, 2 \mathrm{H}, \mathrm{Ar}-\mathrm{H}, \mathrm{OH}), 7.25(\mathrm{~d}, J=8 \mathrm{~Hz}, 1 \mathrm{H}, \mathrm{Ar}-\mathrm{H}), 7.52(\mathrm{t}, J=$ $8 \mathrm{~Hz}, 1 \mathrm{H}, \mathrm{Ar}-\mathrm{H}), 7.62(\mathrm{t}, J=8 \mathrm{~Hz}, 1 \mathrm{H}, \mathrm{Ar}-\mathrm{H}), 7.92(\mathrm{~d}, J=8 \mathrm{~Hz}, 1 \mathrm{H}, \mathrm{Ar}-\mathrm{H}), 8.00(\mathrm{q}, J=4 \mathrm{~Hz}, 2 \mathrm{H}, \mathrm{Ar}-\mathrm{H})$, $8.73(\mathrm{~d}, J=4 \mathrm{~Hz}, 1 \mathrm{H}, \mathrm{Ar}-\mathrm{H}) ;{ }^{13} \mathrm{C}-\mathrm{NMR}\left(100 \mathrm{MHz}, \mathrm{DMSO}-d_{6}\right) \delta: 20.89\left(-\mathrm{CH}_{3}\right), 29.71(\mathrm{C} 11), 41.54(\mathrm{C} 12)$, 94.85 (q, $J=32 \mathrm{~Hz}, \mathrm{C} 20), 112.86$ (C16), 115.82 (C8), 118.63 (C10), 122.66 (q, $J=288 \mathrm{~Hz}, \mathrm{C} 21), 123.31$ (C4), 123.43 (C2), 125.11 (C3), 126.95 (C17), 128.00 (C7), 128.85 (C1), 129.10 (C18), 129.83 (C19), 130.61 (C14), 132.80 (C6), 133.52 (C5), 148.59 (C9), 150.30 (C15) (C13), 164.50 (C=O); IR (KBr) $v_{\max }\left(\mathrm{cm}^{-1}\right)$ : 3287 (OH), $1765(\mathrm{C}=\mathrm{O}), 1628,1600(\mathrm{Ar}), 812\left(\mathrm{CF}_{3}\right)$; HRMS (ESI): $\mathrm{m} / \mathrm{z}$ calcd for $\mathrm{C}_{22} \mathrm{H}_{15} \mathrm{~F}_{3} \mathrm{O}_{4}[\mathrm{M}-\mathrm{H}]^{+}$: 399.0844; found: 399.0805 .

12-Bromo-2-hydroxy-2-(trifluoromethyl)-2a,10c-dihydro-2H,3H-benzo[f]chromeno[3,4-c]chromen-3-one (3e): Crystallization from ethyl acetate-petroleum ether, white crystal; M.p. $158.7 \sim 159.9{ }^{\circ} \mathrm{C} ;{ }^{1} \mathrm{H}-\mathrm{NMR}$ $\left(\mathrm{CDCl}_{3}, 400 \mathrm{MHz}\right) \delta: 3.65(\mathrm{~d}, J=4 \mathrm{~Hz}, 1 \mathrm{H}, \mathrm{CH}), 5.18(\mathrm{~d}, J=4 \mathrm{~Hz}, 1 \mathrm{H}, \mathrm{CH}), 7.64(\mathrm{~d}, J=4 \mathrm{~Hz}, 1 \mathrm{H}, \mathrm{Ar}-\mathrm{H})$, $6.97(\mathrm{~d}, J=4 \mathrm{~Hz}, 1 \mathrm{H}, \mathrm{Ar}-\mathrm{H}), 7.28 \sim 7.32(\mathrm{~m}, 2 \mathrm{H}, \mathrm{Ar}-\mathrm{H}), 7.42(\mathrm{~s}, 1 \mathrm{H},-\mathrm{OH}), 7.61(\mathrm{t}, J=4 \mathrm{~Hz}, 1 \mathrm{H}, \mathrm{Ar}-\mathrm{H})$, $7.72(\mathrm{t}, J=4 \mathrm{~Hz}, 1 \mathrm{H}, \mathrm{Ar}-\mathrm{H}), 7.95 \sim 7.99(\mathrm{~m}, 3 \mathrm{H}, \mathrm{Ar}-\mathrm{H}) ;{ }^{13} \mathrm{C} \mathrm{NMR}\left(100 \mathrm{MHz}, \mathrm{CDCl}_{3}\right)$ 8: $30.96(\mathrm{C} 11), 39.14$ (C12), 95.84 (q, J = 26 Hz, C20), 115.03 (C16), 115.32 (C18), 116.88 (C8), 119.44 (C10), 120.78 (C4), 121.93 ( $\mathrm{q}, J=229 \mathrm{~Hz}, \mathrm{C} 21), 122.47$ (C2), 126.36 (C), 128.90 (C7), 129.26 (C1), 130.11 (C17), 131.28 (C6), 131.39 (C5), 131.49 (C14), 132.99 (C19), 147.43 (C9), 151.76 (C15), 168.00 (C13); IR (KBr) $v_{\max }\left(\mathrm{cm}^{-1}\right): 3408$ (OH), $1740(\mathrm{C}=\mathrm{O}), 1628,1471(\mathrm{Ar}), 809\left(\mathrm{CF}_{3}\right)$; HRMS (ESI): $m / z$ calcd for $\mathrm{C}_{21} \mathrm{H}_{11} \mathrm{BrF}_{3} \mathrm{O}_{4}[\mathrm{M}-\mathrm{H}]^{+}:$: 462.9793; found: 462.9793 .

7-Bromo-2-hydroxy-2-(trifluoromethyl)-2a,10c-dihydro-2H,3H-benzo[f]chromeno[3,4-c]chromen-3-one (3f): Eluent: EA:PE:AcOH = 2:8:0.1; white crystal; M.p.185.0 186.9 ${ }^{\circ} \mathrm{C} ;{ }^{1} \mathrm{H}-\mathrm{NMR}\left(\mathrm{CDCl}_{3}, 400 \mathrm{MHz}\right) \delta: 3.12$ $(\mathrm{d}, J=6 \mathrm{~Hz}, 1 \mathrm{H}, \mathrm{CH}), 5.19(\mathrm{~d}, J=6 \mathrm{~Hz}, 1 \mathrm{H}, \mathrm{CH}), 6.53(\mathrm{~d}, J=8 \mathrm{~Hz}, 1 \mathrm{H}, \mathrm{Ar}-\mathrm{H}), 6.80(\mathrm{t}, J=8 \mathrm{~Hz}, 1 \mathrm{H}$, Ar-H), $7.11(\mathrm{~d}, J=8 \mathrm{~Hz}, 1 \mathrm{H}, \mathrm{Ar}-\mathrm{H}), 7.26(\mathrm{t}, J=8 \mathrm{~Hz}, 1 \mathrm{H}, \mathrm{Ar}-\mathrm{H}), 7.34(\mathrm{~d}, J=2 \mathrm{~Hz}, 1 \mathrm{H}, \mathrm{Ar}-\mathrm{H}), 7.41(\mathrm{~s}$, $1 \mathrm{H},-\mathrm{OH}), 7.80(\mathrm{~d}, J=8 \mathrm{~Hz}, 1 \mathrm{H}, \mathrm{Ar}-\mathrm{H}), 7.88 \sim 7.92(\mathrm{t}, J=8 \mathrm{~Hz}, 2 \mathrm{H}, \mathrm{Ar}-\mathrm{H}), 8.17(\mathrm{~s}, 1 \mathrm{H}, \mathrm{Ar}-\mathrm{H}) ;{ }^{13} \mathrm{C}$ NMR $\left(100 \mathrm{MHz}, \mathrm{CDCl}_{3}\right) \delta: 31.19(\mathrm{~d}, J=3 \mathrm{~Hz}, \mathrm{C} 11), 39.37$ (C12), 95.65 (q, J = $\left.33 \mathrm{~Hz}, \mathrm{C} 20\right), 116.57$ (C16), 117.74 (C18), 117.93 (C1), 118.21 (C8), 120.26 (C10), 122.09 (q, J = 287 Hz, C21), 122.73 (C4), 124.67 (C3), 127.37 (C7), 129.93 (C17), 130.10 (C19), 130.41 (C6), 131.11 (C2), 131.94 (C14), 132.39 (C5), 147.58 (C9), 152.61 (C15), 167.96 (C13); IR (KBr) $v_{\max }\left(\mathrm{cm}^{-1}\right)$ : $3360(\mathrm{OH}), 1723$ (C=O), 1583, 1479 (Ar), $758\left(\mathrm{CF}_{3}\right)$; HRMS (ESI): $\mathrm{m} / z$ calcd for $\mathrm{C}_{21} \mathrm{H}_{11} \mathrm{BrF}_{3} \mathrm{O}_{4}[\mathrm{M}-\mathrm{H}]^{+}:$462.9793; found: 462.9791 . 
7-Bromo-2-hydroxy-14-methoxy-2-(trifluoromethyl)-2a,10c-dihydro-2H,3H-benzo[f]chromeno[3,4-c]chromen3-one (3g): Crystallization from ethyl acetate-petroleum ether, white crystal; M.p. $204.3 \sim 204.8^{\circ} \mathrm{C}$; ${ }^{1} \mathrm{H}-\mathrm{NMR}\left(\mathrm{CDCl}_{3}, 400 \mathrm{MHz}\right) \delta: 3.72(\mathrm{~d}, J=4 \mathrm{~Hz}, 1 \mathrm{H}, \mathrm{CH}), 5.19(\mathrm{~d}, J=4 \mathrm{~Hz}, 1 \mathrm{H}, \mathrm{CH}), 6.09(\mathrm{~d}, J=8 \mathrm{~Hz}$, $1 \mathrm{H}, \mathrm{Ar}-\mathrm{H}), 7.33(\mathrm{~d}, J=8 \mathrm{~Hz}, 1 \mathrm{H}, \mathrm{Ar}-\mathrm{H}), 7.45(\mathrm{~s}, 1 \mathrm{H},-\mathrm{OH}), 7.79(\mathrm{~d}, J=8 \mathrm{~Hz}, 1 \mathrm{H}, \mathrm{Ar}-\mathrm{H}), 7.89(\mathrm{t}, J=8 \mathrm{~Hz}$, 2H, Ar-H), $8.16(\mathrm{~s}, 1 \mathrm{H}, \mathrm{Ar}-\mathrm{H}) ;{ }^{13} \mathrm{C}-\mathrm{NMR}\left(100 \mathrm{MHz}, \mathrm{CDCl}_{3}\right) \delta: 31.28$ (q, J = $\left.3 \mathrm{~Hz}, \mathrm{C} 11\right), 39.33$ (C12), $56.35\left(-\mathrm{OCH}_{3}\right), 95.95$ (q, J = 33 Hz, C20), 112.51 (C17), 116.67 (C19), 118.18 (C18), 118.69 (C1), 119.07 (C8), 120.20 (C10), 122.07 (q, J = 286 Hz, C21), 122.34 (C4), 124.72 (C3), 129.88 (C7), 130.37 (C6), 131.05 (C2), 131.87 (C14), 132.37 (C5), 142.33 (C16), 147.62 (C15), 148.77 (C9), 167.90 (C13); IR (KBr) $v_{\max }$ $\left(\mathrm{cm}^{-1}\right)$ : $3416(\mathrm{OH}), 1762(\mathrm{C}=\mathrm{O}), 1580(\mathrm{Ar}), 865\left(\mathrm{CF}_{3}\right)$; HRMS (ESI): $\mathrm{m} / z$ calcd for $\mathrm{C}_{22} \mathrm{H}_{14} \mathrm{BrF}_{3} \mathrm{O}_{5}[\mathrm{M}-$ $\mathrm{H}]^{+}$: 492.9898; found: 492.9850 .

7-Bromo-2-hydroxy-13-methoxy-2-(trifluoromethyl)-2a,10c-dihydro-2H,3H-benzo[f]chromeno[3,4-c]chromen3-one (3h): Eluent: EA:PE:AcOH = 1:8:0.25; white acicular crystal; M.p. $162.1 \sim 163.0{ }^{\circ} \mathrm{C} ;{ }^{1} \mathrm{H}-\mathrm{NMR}$ $\left(\mathrm{CDCl}_{3}, 400 \mathrm{MHz}\right) \delta: 3.65(\mathrm{~d}, J=8 \mathrm{~Hz}, 1 \mathrm{H}, \mathrm{CH}), 3.74\left(\mathrm{~s}, 3 \mathrm{H}, \mathrm{CH}_{3}\right), 5.08(\mathrm{~d}, J=8 \mathrm{~Hz}, 1 \mathrm{H}, \mathrm{CH}), 6.32 \sim 6.38$ $(\mathrm{m}, 2 \mathrm{H}, \mathrm{Ar}-\mathrm{H}), 6.63(\mathrm{~d}, J=4 \mathrm{~Hz}, 1 \mathrm{H}, \mathrm{Ar}-\mathrm{H}), 7.30(\mathrm{~d}, J=8 \mathrm{~Hz}, 1 \mathrm{H}, \mathrm{Ar}-\mathrm{H}), 7.37(\mathrm{~s}, 1 \mathrm{H},-\mathrm{OH}), 7.76\left(\mathrm{dd}, J_{1}=\right.$ $\left.8 \mathrm{~Hz}, J_{2}=2.4 \mathrm{~Hz}, 1 \mathrm{H}, \mathrm{Ar}-\mathrm{H}\right), 7.86(\mathrm{t}, J=8 \mathrm{~Hz}, 1 \mathrm{H}, \mathrm{Ar}-\mathrm{H}), 8.13(\mathrm{~d}, J=1.6 \mathrm{~Hz}, 1 \mathrm{H}, \mathrm{Ar}-\mathrm{H}) ;{ }^{13} \mathrm{C}$ NMR $\left(100 \mathrm{MHz}, \mathrm{CDCl}_{3}\right)$ 8: $30.68(\mathrm{q}, J=3 \mathrm{~Hz}, \mathrm{C} 11), 39.57(\mathrm{C} 12), 55.45\left(-\mathrm{OCH}_{3}\right), 95.42(\mathrm{q}, \mathrm{J}=33 \mathrm{~Hz}, \mathrm{C} 20)$, 102.23 (C16), 109.62 (C18), 109.89 (C1), 116.74 (C8), 118.19 (C14), 120.20 (C10), 122.03 (q, J = 286 Hz, C21), 124.67 (C4), 128.08 (C3), 129.79 (C7), 130.37 (C6), 131.07 (C2), 131.88 (C19), 132.37 (C5), 147.48 (C9), 153.57 (C15), 161.02 (C17), 168.08 (C13); IR (KBr) $v_{\max }\left(\mathrm{cm}^{-1}\right)$ : $3419(\mathrm{OH}), 1737$ (C=O), 1580, 1499 (Ar), $812\left(\mathrm{CF}_{3}\right)$; HRMS (ESI): $\mathrm{m} / z$ calcd for $\mathrm{C}_{22} \mathrm{H}_{14} \mathrm{BrF}_{3} \mathrm{O}_{5}[\mathrm{M}-\mathrm{H}]^{+}:$: 492.9898; found: 492.9510.

7-Bromo-12-chloro-2-hydroxy-2-(trifluoromethyl)-2a,10c-dihydro-2H,3H-benzo[f]chromeno[3,4-c]chromen-3-one (3i): Eluent: EA:PE:AcOH = 1:8:0.25; white crystal; M.p. $175.3 \sim 176.1{ }^{\circ} \mathrm{C} ;{ }^{1} \mathrm{H}-\mathrm{NMR}\left(\mathrm{CDCl}_{3}, 400 \mathrm{MHz}\right) \delta$ : $3.70(\mathrm{~d}, J=6 \mathrm{~Hz}, 1 \mathrm{H}, \mathrm{CH}), 5.15(\mathrm{~d}, J=6 \mathrm{~Hz}, 1 \mathrm{H}, \mathrm{CH}), 6.47(\mathrm{~s}, 1 \mathrm{H}, \mathrm{Ar}-\mathrm{H}), 7.06(\mathrm{~d}, J=8 \mathrm{~Hz}, 1 \mathrm{H}, \mathrm{Ar}-\mathrm{H})$, $7.22(\mathrm{~d}, J=4 \mathrm{~Hz}, 1 \mathrm{H}, \mathrm{Ar}-\mathrm{H}), 7.35(\mathrm{~d}, J=8 \mathrm{~Hz}, 1 \mathrm{H}, \mathrm{Ar}-\mathrm{H}), 7.40(\mathrm{~s}, 1 \mathrm{H},-\mathrm{OH}), 7.80 \sim 7.93(\mathrm{~m}, 3 \mathrm{H}, \mathrm{Ar}-\mathrm{H})$, 8.18 (s, 1H, Ar-H); ${ }^{13} \mathrm{C}-\mathrm{NMR}\left(100 \mathrm{MHz}, \mathrm{CDCl}_{3}\right)$ 8: 31.09 (d, J = $\left.2 \mathrm{~Hz}, \mathrm{C} 11\right), 39.11$ (C12), 95.83 (q, J = $33 \mathrm{~Hz}, \mathrm{C} 20), 115.72$ (C16), 118.20 (C1), 119.21 (C8), 119.69 (C10), 120.48 (C4), 121.94 (q, J = 286 Hz, C21), 124.26 (C3), 127.07 (C18), 127.86 (C7), 130.12 (C17), 130.27 (C19), 130.36 (C6), 131.30 (C2), 132.26 (C14), 132.47 (C5), 147.63 (C9), 151.22 (C15), 167.64 (C13); IR (KBr) $v_{\max }\left(\mathrm{cm}^{-1}\right)$ : $3430(\mathrm{OH}), 1748$ (C=O), 1583, 1504 (Ar), $812\left(\mathrm{CF}_{3}\right)$; HRMS (ESI): $m / z$ calcd for $\mathrm{C}_{21} \mathrm{H}_{11} \mathrm{BrClF}_{3} \mathrm{O}_{4}[\mathrm{M}+\mathrm{H}]^{+}:$498.9560; found: 498.9331 .

2-Hydroxy-3-oxo-2-(trifluoromethyl)-2a,10c-dihydro-2H,3H-benzo[f]chromeno[3,4-c]chromene-8-carbonitrile (3j): Eluent: EA:PE:AcOH = 1:4:0.25; white crystal; M.p. 174.7 175.5 ${ }^{\circ} \mathrm{C} ;{ }^{1} \mathrm{H}-\mathrm{NMR}\left(\mathrm{CDCl}_{3}, 400 \mathrm{MHz}\right) \delta$ : $3.32\left(\mathrm{dd}, J_{1}=16 \mathrm{~Hz}, J_{2}=2 \mathrm{~Hz}, 1 \mathrm{H}, \mathrm{CH}\right), 5.34(\mathrm{~d}, J=8 \mathrm{~Hz}, 1 \mathrm{H}, \mathrm{CH}), 5.70(\mathrm{~s}, 1 \mathrm{H},-\mathrm{OH}), 6.55\left(\mathrm{dd}, J_{1}=8\right.$ $\left.\mathrm{Hz}, J_{2}=0.8 \mathrm{~Hz}, 1 \mathrm{H}, \mathrm{Ar}-\mathrm{H}\right), 6.70(\mathrm{t}, J=8 \mathrm{~Hz}, 1 \mathrm{H}, \mathrm{Ar}-\mathrm{H}), 6.80(\mathrm{~d}, J=4 \mathrm{~Hz}, 1 \mathrm{H}, \mathrm{Ar}-\mathrm{H}), 7.09\left(\mathrm{td}, J_{1}=8 \mathrm{~Hz}\right.$, $\left.J_{2}=1.6 \mathrm{~Hz}, 1 \mathrm{H}, \mathrm{Ar}-\mathrm{H}\right), 7.48(\mathrm{~d}, J=8 \mathrm{~Hz}, 1 \mathrm{H}, \mathrm{Ar}-\mathrm{H}), 7.59\left(\mathrm{dd}, J_{1}=8 \mathrm{~Hz}, J_{2}=1.6 \mathrm{~Hz}, 1 \mathrm{H}, \mathrm{Ar}-\mathrm{H}\right), 7.87(\mathrm{~d}$, $J=12 \mathrm{~Hz}, 1 \mathrm{H}, \mathrm{Ar}-\mathrm{H}), 7.94(\mathrm{~d}, J=12 \mathrm{~Hz}, 1 \mathrm{H}, \mathrm{Ar}-\mathrm{H}), 8.24(\mathrm{~d}, J=0.8 \mathrm{~Hz}, 1 \mathrm{H}, \mathrm{Ar}-\mathrm{H}) ;{ }^{13} \mathrm{C}-\mathrm{NMR}(100 \mathrm{MHz}$,

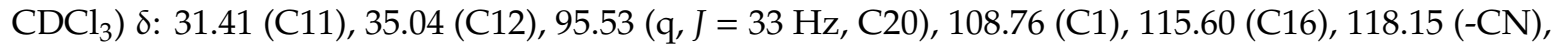
118.87 (C18), 119.51 (C7), 122.42 (q, J = $286 \mathrm{~Hz}, \mathrm{C} 21), 121.47$ (C8), 124.67 (C10), 125.98 (C3), 127.84 (C17), 128.04 (C19), 129.11 (C4), 130.00 (C5), 130.35 (C6), 132.86 (C14)), 134.54 (C2), 152.40 (C15, C9), 167.22 (C13); IR (KBr) $v_{\max }\left(\mathrm{cm}^{-1}\right): 3419(\mathrm{OH}), 2228(\mathrm{CN}), 1748(\mathrm{C}=\mathrm{O}), 1628,1585$ (Ar), $753\left(\mathrm{CF}_{3}\right)$; HRMS (ESI): $\mathrm{m} / \mathrm{z}$ calcd for $\mathrm{C}_{22} \mathrm{H}_{12} \mathrm{~F}_{3} \mathrm{NO}_{4}[\mathrm{M}-\mathrm{H}]^{+}:$410.0640; found: 410.0600 .

2-Hydroxy-13-methoxy-3-oxo-2-(trifluoromethyl)-2a,10c-dihydro-2H,3H-benzo[f]chromeno[3,4-c]chromene8-carbonitrile (3k): Eluent: EA:PE:AcOH = 1:7:0.25; white acicular crystal; M.p. $169.7 \sim 170.4{ }^{\circ} \mathrm{C}$; ${ }^{1} \mathrm{H}-\mathrm{NMR}\left(\mathrm{CDCl}_{3}, 400 \mathrm{MHz}\right) \delta: 3.68(\mathrm{~d}, J=6 \mathrm{~Hz}, 1 \mathrm{H}, \mathrm{CH}), 3.74\left(\mathrm{~s}, 3 \mathrm{H}, \mathrm{CH}_{3}\right), 5.13(\mathrm{~d}, J=6 \mathrm{~Hz}, 1 \mathrm{H}, \mathrm{CH})$, $5.30(\mathrm{~s}, 1 \mathrm{H},-\mathrm{OH}), 6.34(\mathrm{~d}, J=4 \mathrm{~Hz}, 1 \mathrm{H}, \mathrm{Ar}-\mathrm{H}), 6.64(\mathrm{~d}, J=4 \mathrm{~Hz}, 1 \mathrm{H}, \mathrm{Ar}-\mathrm{H}), 7.25(\mathrm{~d}, J=4 \mathrm{~Hz}, 1 \mathrm{H}, \mathrm{Ar}-\mathrm{H})$, $7.43(\mathrm{~d}, J=12 \mathrm{~Hz}, 1 \mathrm{H}, \mathrm{Ar}-\mathrm{H}), 7.85\left(\mathrm{dd}, J_{1}=12 \mathrm{~Hz}, J_{2}=2 \mathrm{~Hz}, 1 \mathrm{H}, \mathrm{Ar}-\mathrm{H}\right), 8.03(\mathrm{~d}, J=8 \mathrm{~Hz}, 1 \mathrm{H}, \mathrm{Ar}-\mathrm{H})$, $8.11(\mathrm{~d}, J=4 \mathrm{~Hz}, 1 \mathrm{H}, \mathrm{Ar}-\mathrm{H}), 8.36(\mathrm{~s}, 1 \mathrm{H}, \mathrm{Ar}-\mathrm{H}) ;{ }^{13} \mathrm{C} \mathrm{NMR}\left(100 \mathrm{MHz}, \mathrm{CDCl}_{3}\right) \delta: 30.69(\mathrm{q}, J=3 \mathrm{~Hz}$, C11), 39.48 (C12), $55.47\left(-\mathrm{OCH}_{3}\right), 95.63$ (q, $\left.J=30 \mathrm{~Hz}, \mathrm{C} 20\right), 102.34$ (C16), 109.10 (C18), 109.93 (C1), 109.99 (-CN), 117.02 (C7), 118.43 (C14), 119.06 (C8), 121.96 (q, J = 286 Hz, C21), 124.39 (C10), 127.86 
(C3), 129.08 (C4), 130.17 (C19), 131.36 (C5), 133.48 (C6), 134.92 (C2), 149.44 (C9), 153.56 (C15), 161.14 (C17), $167.55(\mathrm{C} 13)$; IR (KBr) $v_{\max }\left(\mathrm{cm}^{-1}\right)$ : $3430(\mathrm{OH}), 2228(\mathrm{CN}), 1742(\mathrm{C}=\mathrm{O}), 1619,1580(\mathrm{Ar}), 817\left(\mathrm{CF}_{3}\right)$; HRMS (ESI): $m / z$ calcd for $\mathrm{C}_{23} \mathrm{H}_{13} \mathrm{~F}_{3} \mathrm{NO}_{4}[\mathrm{M}-\mathrm{H}]^{+}: 440.0746$; found: 440.0743 .

7-Hydroxy-7-(trifluoromethyl)-6a,12b-dihydro-6H,7H-chromeno[3,4-c]chromen-6-one (31): Eluent: EA:PE:AcOH = 2:8:0.25; white acicular crystal; M.p. $151.8 \sim 152.6{ }^{\circ} \mathrm{C} ;{ }^{1} \mathrm{H}-\mathrm{NMR}\left(\mathrm{CDCl}_{3}, 400 \mathrm{MHz}\right) \delta$ : $3.67(\mathrm{~d}, J=6 \mathrm{~Hz}, 1 \mathrm{H}, \mathrm{CH}), 4.59(\mathrm{~d}, J=6 \mathrm{~Hz}, 1 \mathrm{H}, \mathrm{CH}), 6.69(\mathrm{~d}, J=8 \mathrm{~Hz}, 1 \mathrm{H}, \mathrm{Ar}-\mathrm{H}), 6.91(\mathrm{t}, J=8 \mathrm{~Hz}, 1 \mathrm{H}$, Ar-H), $7.07(\mathrm{~d}, J=8 \mathrm{~Hz}, 1 \mathrm{H}, \mathrm{Ar}-\mathrm{H}), 7.16(\mathrm{~d}, J=8 \mathrm{~Hz}, 1 \mathrm{H}, \mathrm{Ar}-\mathrm{H}), 7.23 \sim 7.28(\mathrm{~m}, 1 \mathrm{H}, \mathrm{Ar}-\mathrm{H}), 7.38(\mathrm{t}, J=$ $8 \mathrm{~Hz}, 1 \mathrm{H}, \mathrm{Ar}-\mathrm{H}), 7.46 \sim 7.52(\mathrm{~m}, 2 \mathrm{H}, \mathrm{Ar}-\mathrm{H}) ;{ }^{13} \mathrm{C}-\mathrm{NMR}\left(100 \mathrm{MHz}, \mathrm{CDCl}_{3}\right) \delta: 34.98$ (C3), 39.91 (C2), 95.50 (q, $J=32 \mathrm{~Hz}, \mathrm{C} 16), 117.47$ (C12), 117.58 (C14), 118.41 (C6), 121.96 (C8), 122.01 (q, J = 287 Hz, C17), 122.54 (C13), 125.65 (C7), 127.45 (C15), 129.91 (C9), 129.99 (C10), 130.09 (C4), 149.42 (C5), 152.36 (C11), $168.11(\mathrm{C} 1) ; \mathrm{IR}(\mathrm{KBr}) v_{\max }\left(\mathrm{cm}^{-1}\right): 3414(\mathrm{OH}), 1726(\mathrm{C}=\mathrm{O}), 1588,1487(\mathrm{Ar}), 756\left(\mathrm{CF}_{3}\right) ; \mathrm{HRMS}(\mathrm{ESI}): \mathrm{m} / \mathrm{z}$ calcd for $\mathrm{C}_{17} \mathrm{H}_{10} \mathrm{~F}_{3} \mathrm{O}_{4}[\mathrm{M}-\mathrm{H}]^{+}$: 335.0531; found: 335.0298 .

1,7-Dihydroxy-7-(trifluoromethyl)-6a,12b-dihydro-6H,7H-chromeno[3,4-c]chromen-6-one (3m): Eluent: EA:PE:AcOH = 1:5:0.1; white solid; M.p. $138.5 \sim 139.3{ }^{\circ} \mathrm{C} ;{ }^{1} \mathrm{H}-\mathrm{NMR}\left(\mathrm{CDCl}_{3}, 400 \mathrm{MHz}\right) \delta: 3.60$ $(\mathrm{d}, J=4 \mathrm{~Hz}, 1 \mathrm{H}, \mathrm{CH}), 4.47(\mathrm{~d}, J=4 \mathrm{~Hz}, 1 \mathrm{H}, \mathrm{CH}), 5.12(\mathrm{~s}, 1 \mathrm{H},-\mathrm{OH}), 6.61(\mathrm{~d}, J=2 \mathrm{~Hz}, 1 \mathrm{H}, \mathrm{Ar}-\mathrm{H}), 6.75 \sim 6.80$ $(\mathrm{m}, 2 \mathrm{H}, \mathrm{Ar}-\mathrm{H}), 6.87(\mathrm{t}, J=4 \mathrm{~Hz}, 1 \mathrm{H}, \mathrm{Ar}-\mathrm{H}), 7.01(\mathrm{~d}, J=8 \mathrm{~Hz}, 1 \mathrm{H}, \mathrm{Ar}-\mathrm{H}), 7.20(\mathrm{t}, J=4 \mathrm{~Hz}, 1 \mathrm{H}, \mathrm{Ar}-\mathrm{H}), 7.31$ $(\mathrm{d}, J=8 \mathrm{~Hz}, 1 \mathrm{H}, \mathrm{Ar}-\mathrm{H}) ;{ }^{13} \mathrm{C}$ NMR $\left(100 \mathrm{MHz}, \mathrm{CDCl}_{3}\right) \delta: 34.33$ (q, $\left.J=2 \mathrm{~Hz}, \mathrm{C} 3\right), 40.11(\mathrm{C} 2), 95.47$ (q, $J=$ $26 \mathrm{~Hz}, \mathrm{C} 16), 104.79$ (C8), 112.71 (C12), 114.01 (C6), 117.52 (C4), 118.82 (C14), 121.98 (q, J = $229 \mathrm{~Hz}, \mathrm{C} 17)$, 122.49 (C13), 127.41 (C7), 129.84 (C15), 130.75 (C10), 150.13 (C5), 152.30 (C11), 156.88 (C9), 168.02 (C1); IR $(\mathrm{KBr}) v_{\max }\left(\mathrm{cm}^{-1}\right): 3405(\mathrm{OH}), 1723(\mathrm{C}=\mathrm{O}), 1625,1597(\mathrm{Ar}), 758\left(\mathrm{CF}_{3}\right)$; HRMS (ESI): $\mathrm{m} / z$ calcd for $\mathrm{C}_{17} \mathrm{H}_{10} \mathrm{~F}_{3} \mathrm{O}_{5}[\mathrm{M}-\mathrm{H}]^{+}$: 351.0480; found: 351.0236.

2,7-Dihydroxy-9-methoxy-7-(trifluoromethyl)-6a,12b-dihydro-6H,7H-chromeno[3,4-c]chromen-6-one (3n): Eluent: DCM:PE:AcOH = 4:8:1; yellowish crystal; M.p. 187.8 $188.5^{\circ} \mathrm{C} ;{ }^{1} \mathrm{H}-\mathrm{NMR}$ (DMSO- $d_{6}, 400 \mathrm{MHz}$ ) $\delta: 3.51(\mathrm{~d}, J=4 \mathrm{~Hz}, 1 \mathrm{H}, \mathrm{CH}), 3.79\left(\mathrm{~s}, 3 \mathrm{H}, \mathrm{CH}_{3}\right), 4.82(\mathrm{~d}, J=4 \mathrm{~Hz}, 1 \mathrm{H}, \mathrm{CH}), 6.23(\mathrm{~s}, 1 \mathrm{H},-\mathrm{OH}), 6.60\left(\mathrm{dd}, J_{1}\right.$ $\left.=8 \mathrm{~Hz}, J_{2}=1.6 \mathrm{~Hz}, 1 \mathrm{H}, \mathrm{Ar}-\mathrm{H}\right), 6.87(\mathrm{~d}, J=8 \mathrm{~Hz}, 1 \mathrm{H}, \mathrm{Ar}-\mathrm{H}), 6.98 \sim 7.16(\mathrm{~m}, 4 \mathrm{H}, \mathrm{Ar}-\mathrm{H}), 8.62(\mathrm{~s}, 1 \mathrm{H}, \mathrm{Ar}-\mathrm{H})$, $9.24(\mathrm{~s}, 1 \mathrm{H},-\mathrm{OH}) ;{ }^{13} \mathrm{C}$ NMR (100 MHz, DMSO-d $\left.{ }^{6}\right)$ 8: 33.73 (C3), $42.18(\mathrm{C} 2), 56.21\left(-\mathrm{OCH}_{3}\right), 95.23$ (q, $J=26$ Hz, C16), 112.63 (C13), 112.98 (C7), 114.68 (C9), 116.71 (C15), 118.36 (C14), 121.27 (C6), 122.65 (C10), 122.69 (q, J = 289 Hz, C17), 124.47 (C4), 140.17 (C5), 144.60 (C12), 148.90 (C11), 154.33 (C8), 164.44 (C1); IR (KBr) $v_{\max }\left(\mathrm{cm}^{-1}\right): 3453(\mathrm{OH}), 1728(\mathrm{C}=\mathrm{O}), 1605$ (Ar), $730\left(\mathrm{CF}_{3}\right)$; HRMS (ESI): $m / z$ calcd for $\mathrm{C}_{18} \mathrm{H}_{12} \mathrm{~F}_{3} \mathrm{O}_{6}[\mathrm{M}-\mathrm{H}]^{+}$: 381.0586; found: 381.0317 .

11-Chloro-2,7-dihydroxy-7-(trifluoromethyl)-6a,12b-dihydro-6H,7H-chromeno[3,4-c]chromen-6-one (3o): Eluent: DCM:PE:AcOH = 4:8.5:0.5; white solid; M.p. $192.5 \sim 193.3{ }^{\circ} \mathrm{C} ;{ }^{1} \mathrm{H}-\mathrm{NMR}\left(\mathrm{DMSO}-d_{6}, 400 \mathrm{MHz}\right) \delta$ : $3.61(\mathrm{~d}, J=4 \mathrm{~Hz}, 1 \mathrm{H}, \mathrm{CH}), 4.86(\mathrm{~d}, J=4 \mathrm{~Hz}, 1 \mathrm{H}, \mathrm{CH}), 6.25(\mathrm{~s}, 1 \mathrm{H},-\mathrm{OH}), 6.62(\mathrm{~d}, J=8 \mathrm{~Hz}, 1 \mathrm{H}, \mathrm{Ar}-\mathrm{H})$, $6.90(\mathrm{~d}, J=8 \mathrm{~Hz}, 1 \mathrm{H}, \mathrm{Ar}-\mathrm{H}), 7.07(\mathrm{~d}, J=12 \mathrm{~Hz}, 1 \mathrm{H}, \mathrm{Ar}-\mathrm{H}), 7.43\left(\mathrm{dd}, J_{1}=8 \mathrm{~Hz}, J_{2}=2.4 \mathrm{~Hz}, 1 \mathrm{H}, \mathrm{Ar}-\mathrm{H}\right)$, 7.59 (s, 1H, Ar-H), 9.32 (s, 1H, -OH); ${ }^{13} \mathrm{C}-\mathrm{NMR}\left(100 \mathrm{MHz}, \mathrm{DMSO}-d_{6}\right)$ ) 33.46 (C3), 41.48 (C2), 95.35 (q, $J=32 \mathrm{~Hz}, \mathrm{C} 16), 112.77$ (C12), 114.82 (C7), 116.88 (C9), 119.54 (C6), 122.25 (C14), 122.49 (q, J = 288 Hz, C17), 123.93 (C13), 126.56 (C15), 129.84 (C10), 130.79 (C4), 144.51 (C5), 149.64 (C11), 154.41 (C8), 164.13 (C1); IR (KBr) $v_{\max }\left(\mathrm{cm}^{-1}\right): 3273(\mathrm{OH}), 1731(\mathrm{C}=\mathrm{O}), 1611,1482(\mathrm{Ar}), 825\left(\mathrm{CF}_{3}\right) ;$ HRMS (ESI): $\mathrm{m} / \mathrm{z}$ calcd for $\mathrm{C}_{17} \mathrm{H}_{9} \mathrm{ClF}_{3} \mathrm{O}_{5}[\mathrm{M}-\mathrm{H}]^{+}$: 385.0091; found: 384.9819 .

1,7-Dihydroxy-3-methyl-7-(trifluoromethyl)-6a,12b-dihydro-6H,7H-chromeno[3,4-c]chromen-6-one (3p): Crystallization from ethyl acetate-petroleum ether, white solid; M.p. $170.8 \sim 171.5^{\circ} \mathrm{C} ; 1 \mathrm{H}-\mathrm{NMR}\left(\mathrm{CDCl}_{3}\right.$, $400 \mathrm{MHz}) \delta: 2.42\left(\mathrm{~s}, 3 \mathrm{H}, \mathrm{CH}_{3}\right), 3.53(\mathrm{~d}, J=4 \mathrm{~Hz}, 1 \mathrm{H}, \mathrm{CH}), 4.58(\mathrm{~d}, J=4 \mathrm{~Hz}, 1 \mathrm{H}, \mathrm{CH}), 5.02(\mathrm{~s}, 1 \mathrm{H},-\mathrm{OH})$, $6.46(\mathrm{~s}, 1 \mathrm{H},-\mathrm{OH}), 6.59\left(\mathrm{dt}, J_{1}=8 \mathrm{~Hz}, J_{2}=0.8 \mathrm{~Hz}, 1 \mathrm{H}, \mathrm{Ar}-\mathrm{H}\right), 6.67(\mathrm{~d}, J=2.4 \mathrm{~Hz}, 1 \mathrm{H}, \mathrm{Ar}-\mathrm{H}), 6.86\left(\mathrm{td}, J_{1}=\right.$ $\left.4 \mathrm{~Hz}, J_{2}=0.8 \mathrm{~Hz}, 1 \mathrm{H}, \mathrm{Ar}-\mathrm{H}\right), 7.03\left(\mathrm{dd}, J_{1}=8 \mathrm{~Hz}, J_{2}=0.8 \mathrm{~Hz}, 1 \mathrm{H}, \mathrm{Ar}-\mathrm{H}\right), 7.21(\mathrm{~d}, J=4 \mathrm{~Hz}, 1 \mathrm{H}, \mathrm{Ar}-\mathrm{H})$, $7.43(\mathrm{~d}, J=0.8 \mathrm{~Hz}, 1 \mathrm{H}, \mathrm{Ar}-\mathrm{H}) ;{ }^{13} \mathrm{C}-\mathrm{NMR}\left(100 \mathrm{MHz}, \mathrm{CDCl}_{3}\right) \delta: 18.95\left(-\mathrm{CH}_{3}\right), 31.20(\mathrm{C} 3), 39.83(\mathrm{C} 2), 95.82$ $(\mathrm{q}, J=26 \mathrm{~Hz}, \mathrm{C} 16), 102.53$ (C12), 113.25 (C8), 114.46 (C6), 117.66 (C4), 118.43 (C14), 122.02 (q, J = 229 Hz, C17), 122.66 (C13), 126.75 (C15), 129.86 (C10), 138.93 (C7), 150.35 (C5), 152.57 (C11), 156.21 (C9), 168.39 
(C1); IR (KBr) ${ }_{\max }\left(\mathrm{cm}^{-1}\right): 3461(\mathrm{OH}), 1706(\mathrm{C}=\mathrm{O}), 1633,1594(\mathrm{Ar}), 753\left(\mathrm{CF}_{3}\right) ; \mathrm{HRMS}(\mathrm{ESI}): \mathrm{m} / z$ calcd for $\mathrm{C}_{18} \mathrm{H}_{12} \mathrm{~F}_{3} \mathrm{O}_{5}[\mathrm{M}-\mathrm{H}]^{+}$: 365.0637; found: 365.0378 .

\section{Conclusions}

In conclusion, we have developed a novel strategy to obtain chromeno[3,4-c]chromen-6-ones 3a-p, a new kind of dihydrocoumarins, from the reactions of 3-trifluoroacetylcoumarin with phenols in one step. The chemical structures of the title compounds have been verified with the aid of several spectroscopic methods. The X-ray crystal structures of compounds $3 \mathbf{a}$ and $\mathbf{3 n}$ showed the twisted conformation in their cyclic structures. The antifungal activity of the compounds $\mathbf{3 a}-\mathbf{p}$ was assessed against two fungal strains with the mycelial growth rate method. The preliminary results indicated that the phenyl ring at the dihydrocoumarins favors activity against Fusarium monitiforme. Compound 31 displayed the highest antifungal activity of $84.6 \%$ against Fusarium monitiforme. We continue our efforts to obtain new potent, broad spectrum and safe fluorine-bearing coumarins as antifungal drug-like candidates.

Supplementary Materials: The following are available online: Figure S1: Molecular packing of compound 3a (CCDC 1900313) and 3n (CCDC1900314); Table S1: The refinement information and crystallographic data of 3a and $\mathbf{3 n}$; and Figures S2-S17: ${ }^{1} \mathrm{H}-\mathrm{NMR},{ }^{13} \mathrm{C}-\mathrm{NMR}$, and HRMS spectra of compounds $3 \mathbf{a}-\mathbf{p}$.

Author Contributions: Conceptualization and Methodology, C.-1.X.; Experiments and Writing-Original Draft Preparation, J.-p.B.; Writing-Review \& Editing, G.-y.Y.; Analysis-Bioactivity tests, C.-x.W.; Analysis-Crystal analysis, X.Z.; Verification, X.-x.Y.

Funding: This work was supported by the Science and Technology Agency of Henan Province (152102110070, 182102110016) and Guidance Program for Key Scientific Research Items of Higher Education of Henan Province (19B210004).

Conflicts of Interest: The authors declare no conflict of interest.

\section{References}

1. Ayati, A.; Bakhshaiesh, T.O.; Moghimi, S.; Esmaeili, R.; Majidzadeh-A, K.; Safavi, M.; Firoozpour, L.; Emami, S.; Foroumadi, A. Synthesis and biological evaluation of new coumarins bearing 2,4-diaminothiazole-5-carbonyl moiety. Eur. J. Med. Chem. 2018, 155, 483-491. [CrossRef] [PubMed]

2. Chauhan, N.B.; Patel, N.B.; Patel, V.M.; Mistry, B.M. Synthesis and biological evaluation of coumarin clubbed thiazines scaffolds as antimicrobial and antioxidant. Med. Chem. Res. 2018, 27, 2141-2149. [CrossRef]

3. Al-Amiery, A.A.; Al-Majedy, Y.K.; Kadhum, A.A.; Mohamad, A.B. Novel macromolecules derived from coumarin: Synthesis and antioxidant activity. Sci. Rep. 2015, 5, 11825. [CrossRef]

4. Ambekar, S.P.; Dhananjaya, M.C.; Arunkumar, S.; Kumar, M.K.; Shobith, R.; Surender, M.; Obelannavar, K.; Rangappa, K.S. Synthesis of coumarin-benzotriazole hybrids and evaluation of their anti-tubercular activity. Lett. Org. Chem. 2017, 15, 23-31. [CrossRef]

5. Amin, K.M.; Taha, A.M.; George, R.F.; Mohamed, N.M.; Elsenduny, F.F. Synthesis, antitumor activity evaluation, and DNA-binding study of coumarin-based agents. Arch. Pharm. 2018, 351, e1700199. [CrossRef]

6. Zhang, R.R.; Liu, J.; Zhang, Y.; Hou, M.Q.; Zhang, M.Z.; Zhou, F.G.; Zhang, W.H. Microwave-assisted synthesis and antifungal activity of novel coumarin derivatives: Pyrano[3,2-c]chromene-2,5-diones. Eur. J. Med. Chem. 2016, 116, 76-83. [CrossRef] [PubMed]

7. Shi, X.; Lv, C.W.; Li, J.; Hou, Z.; Xiao Hui, Y.; Zhang, Z.D.; Luo, X.X.; Yuan, Z.; Li, M.K. Synthesis, photoluminescent, antibacterial activities and theoretical studies of three novel coumarin and dihydropyran derivatives containing a triphenylamine group. Res. Chem. Intermed. 2015, 41, 8965-8974. [CrossRef]

8. Shen, Y.F.; Liu, L.; Feng, C.Z.; Yang, H.; Chen, C.; Wang, G.X.; Zhu, B. Synthesis and antiviral activity of a new coumarin derivative against spring viraemia of carp virus. Fish Shellfish Immun. 2018, 81, 57-66. [CrossRef] [PubMed]

9. Sangshetti, J.N.; Khan, F.A.K.; Kulkarni, A.A.; Patil, R.H.; Pachpinde, A.M.; Lohar, K.S.; Shinde, D.B. Antileishmanial activity of novel indolyl-coumarin hybrids: Design, synthesis, biological evaluation, molecular docking study and in silico ADME prediction. Bioorg. Med. Chem. Lett. 2016, 26, 829-835. [CrossRef] 
10. Morsy, S.A.; Farahat, A.A.; Nasr, M.N.A.; Tantawy, A.S. Synthesis, molecular modeling and anticancer activity of new coumarin containing compounds. Saudi. Pharm. J. 2017, 25, 873-883. [CrossRef]

11. Wu, J.; Peng, T.; Fang, C.; Leng, Y.; Tong, L.; Li, M.; Rong, Q.; Hua, X.; Jian, D.; Duan, W. Synthesis and Anticancer Activity of 7,8-dihydroxy-4-arylcoumarins. Lett. Drug. Des. Discov. 2015, 12, 366-373. [CrossRef]

12. Sun, J.; Ding, W.X.; Hong, X.P.; Zhang, K.Y. Antioxidant and antitumor activities of 4-arylcoumarins and 4-aryl-3,4-dihydrocoumarins. Biochimie 2014, 107, 203-210.

13. Sun, J.; Ding, W.X.; Hong, X.P.; Zhang, K.Y. Synthesis and antimicrobial activities of 4-aryl-3,4dihydrocoumarins and 4-arylcoumarins. Chem. Nat. Compd. 2012, 48, 16-22. [CrossRef]

14. Pierson, J.T.; Dumètre, A.; Hutter, S.; Delmas, F.; Laget, M.; Finet, J.P.; Azas, N.; Combes, S. Synthesis and antiprotozoal activity of 4-arylcoumarins. J. Cheminf. 2010, 41, 864-869. [CrossRef] [PubMed]

15. Taechowisan, T.; Lu, C.h.; Shen, Y.m.; Lumyong, A. Secondary metabolites from endophytic Streptomyces aureofaciens CMUAc130 and their antifungal activity. Microbiology 2005, 151, 1691-1695. [CrossRef] [PubMed]

16. Jung, J.W.; Kim, N.J.; Yun, H.Y.; Han, Y. Recent advances in synthesis of 4-arylcoumarins. Molecules 2018, 23, 2417. [CrossRef]

17. Pourshojaei, Y.; Jadidi, M.H.; Eskandari, K.; Foroumadi, A.; Asadipour, A. An eco-friendly synthesis of 4-aryl-substituted pyrano-fuzed coumarins as potential pharmacological active heterocycles using molybdenum oxide nanoparticles as an effective and recyclable catalyst. Res. Chem. Intermed. 2018, 44, 4195-4212. [CrossRef]

18. El-Dean, A.M.K.; Zaki, R.M.; Geies, A.A.; Radwan, S.M.; Tolba, M.S. Synthesis and antimicrobial activity of new heterocyclic compounds containing thieno[3,2-]coumarin and pyrazolo[4,3-]coumarin frameworks. Russ. J. Bioorg. Chem. 2013, 39, 553-564.

19. Yin, S.; Yang, X.Y.; Zhang, M.; Zhou, Z.Q.; XU, H.H. Synthesis and fungicidal activities of novel fluorine-containing pyrimithamine derivatives. Chin. J. Synth. Chem. 2013, 21, 317-321.

20. Iaroshenko, V.O.; Ali, S.; Babar, T.M.; Dudkin, S.; Mkrtchyan, S.; Rama, N.H.; Villinger, A.; Langer, P. 4-Chloro-3-(trifluoroacetyl)coumarin as a novel building block for the synthesis of 7-(trifluoromethyl)6H-chromeno[4,3-b]quinolin-6-ones. Tetrahedron Lett. 2011, 52, 373-376. [CrossRef]

21. Vdovenko, S.I.; Gerus, I.I.; Kukhar, V.P. Steric effects on the mechanism of reaction of nucleophilic substitution of $\beta$-substituted alkoxyvinyl trifluoromethyl ketones with four secondary amines. J. Phys. Org. Chem. 2007, 20, 190-200. [CrossRef]

22. Huang, D.F.; Zhang, X.H.; Wang, K.H.; Su, Y.P.; Hu, Y.L. Synthesis of 2-trifluoromethyl-2,3-dihydro1,3,4-oxadiazole derivatives. J. Northwest Normal Univ. 2018, 54, 70-76.

23. Xu, C.L.; Yang, G.Y.; Zhao, M.Q.; Wang, C.X.; Fan, S.F.; Xie, P.H.; Li, X. Microwave assisted one-pot synthesis of novel trifluoromethyl coumarin thiosemicarbazones and their antifungal activities. Curr. Microw. Chem. 2016, 3, 60-67.

24. Yang, G.Y.; Yang, J.T.; Wang, C.X.; Fan, S.F.; Xie, P.H.; Xu, C.L. Microwave-assisted TsOH/SiO ${ }_{2}$-catalyzed one-pot synthesis of novel fluoro-substituted coumarin hydrazones under solvent-free conditions. J. Fluor. Chem. 2014, 168, 1-8. [CrossRef]

25. Fan, H.F.; Wang, X.W.; Zhao, J.W.; Li, X.J.; Gao, J.M.; Zhu, S.Z. Synthesis of 3-trifluoromethyl-substituted benzo[f]chromene derivatives in a one-pot reaction. Synth. Commun. 2013, 43, 2883-2891. [CrossRef]

26. Xian, D.W. Biological Activities Study on 4-arylcoumarins and 4-aryl-3,4 dihydrocoumarins; Nanjing Agricultural University: Nanjing, China, 2011.

27. Zhang, J.; Yang, Y.; Liu, X.H.; Zhu, H.T. Progress in synthesis of chiral dihydrocoumarin derivatives. In Proceedings of the 3rd Symposium on Molecular Chirality in China, Guiyang, China, 30 July-1 August 2010; pp. 83-87.

28. Wallace, K.J.; Belcher, W.J.; Turner, D.R.; Syed, K.F.; Steed, J.W. Slow anion exchange, conformational equilibria, and fluorescent sensing in venus flytrap aminopyridinium-based anion hosts. J. Am. Chem. Soc. 2003, 125, 9699. [CrossRef] [PubMed]

29. Huang, Z.X. Plant Chemical Protection Experiment Instruction, 1st ed.; Agriculture Press: Beijing, China, 1993; pp. 51-52. 
30. Yang, G.Y.; Wang, C.X.; Fan, S.F.; Xie, P.H.; Jin, Q.; Xu, C.L. Microwave assisted solvent-free synthesis of 3-(trifluoroacetyl)coumarins. Chin. J. Org. Chem. 2015, 35, 1173-1178. [CrossRef]

Sample Availability: Samples of the compounds are not available from the authors. 